\title{
Review: Proteomic Techniques for the Development of Flood-Tolerant Soybean
}

\author{
Xin Wang ${ }^{1, *}$ and Setsuko Komatsu ${ }^{2, *}$ \\ 1 College of Agronomy and Biotechnology, China Agricultural University, Beijing 100193, China \\ 2 Faculty of Environmental and Information Sciences, Fukui University of Technology, Fukui 910-8505, Japan \\ * Correspondence: 020350286@163.com (X.W.); skomatsu@fukui-ut.ac.jp (S.K.); Tel.: +86-010-6273-2557 (X.W.); \\ +81-776-29-2466 (S.K.)
}

Received: 13 August 2020; Accepted: 8 October 2020; Published: 12 October 2020

\begin{abstract}
Soybean, which is rich in protein and oil as well as phytochemicals, is cultivated in several climatic zones. However, its growth is markedly decreased by flooding stress, which is caused by climate change. Proteomic techniques were used for understanding the flood-response and -tolerant mechanisms in soybean. Subcellular proteomics has potential to elucidate localized cellular responses and investigate communications among subcellular components during plant growth and under stress stimuli. Furthermore, post-translational modifications play important roles in stress response and tolerance to flooding stress. Although many flood-response mechanisms have been reported, flood-tolerant mechanisms have not been fully clarified for soybean because of limitations in germplasm with flooding tolerance. This review provides an update on current biochemical and molecular networks involved in soybean tolerance against flooding stress, as well as recent developments in the area of functional genomics in terms of developing flood-tolerant soybeans. This work will expedite marker-assisted genetic enhancement studies in crops for developing high-yielding stress-tolerant lines or varieties under abiotic stress.
\end{abstract}

Keywords: proteomics; omics; soybean; flooding; stress tolerant; stress response

\section{Introduction}

Climate change, which occurs naturally in addition to human activities, is a major global concern [1]. Climate change produces alterations in rainfall intensity and patterns, and extremes in precipitation are more frequently limiting the production of food products [2]. The majority of arable lands in the world are prone to unfavorable environmental conditions [3]. Out of all of them, flooding stress causes growth inhibition and ultimately death in most crop species by limiting energy production [4]. Due to the scarcity of available oxygen in waterlogged soil, flooding stress leads to partitioning of oxidative systems in plants, resulting in the accumulation of ethylene and carbon dioxide [5], which impairs and damages root extension. These findings indicate that plant growth is severely affected by flooding due to the limited oxygen levels.

Rice is one of the few flood-tolerant crops; however, it cannot grow under extended periods of complete submergence. Most lowland rice genotypes generally adopt an escape strategy, which is characterized by ethylene-mediated rapid elongation promoted by gibberellins associated with carbohydrate consumption [6]. In deep-water rice, the escape strategy is regulated by two ethylene-responsive factors, SNORKEL1 and SNORKEL2, that trigger considerable internode elongation via gibberellins during flooding $[7,8]$. Some varieties of rice tolerate complete submergence by inhibiting the elongation of submerged stems and leaves, which suppresses the consumption of carbohydrates instead [9]. The gene related to such submergence tolerance is SUBMERGENCE1, which encodes a variable cluster of ethylene-responsive factor genes [10,11]. In such submergence-tolerant rice, 
elongation of stems and leaves was inhibited by suppression of the increase in ethylene concentration, which also decreases plant sensitivity to gibberellins. The plant maintains a balance between carbohydrate supply and demand.

Soybean is considered a unique leguminous crop, because its seed is a rich source of protein, essential amino acids, oil, and metabolizable energy [12]. Although soybean is one of the major agricultural crops, it is particularly sensitive to flooding stress [13]. Its plant growth and grain yield are markedly reduced in flooded soil [13]. When soybean was exposed to flooding at the vegetative growth stage or reproductive growth stage, grain yield and quality were reduced [14]. In addition, secondary aerenchyma was formed and worked as an oxygen pathway under flooded conditions [15]. Furthermore, flooding stress impaired plant growth by inhibiting root elongation and reducing hypocotyl pigmentation [4]. In the root of soybean, ubiquitin-mediated proteolysis was activated [16] and cell death was detected under flooding [17]. These results indicated that flooding causes damage to soybean at the early stage of growth.

To understand flood-response mechanisms in soybean, proteomic analyses were performed. Under flooding, soybean seedlings showed differential regulation of proteins involved in signal transduction, hormonal signaling, transcriptional control, glucose degradation/sucrose accumulation, alcohol fermentation, gamma-aminobutyric acid (GABA) shunt, suppression of reactive oxygen species (ROS) scavenging, mitochondrial impairment, ubiquitin/proteasome-mediated proteolysis, and cell-wall loosening [18-20]. Although flood-response mechanisms of soybean have been explored using proteomic techniques, flood-tolerant mechanisms have not yet been uncovered. For this reason, soybean materials with flooding tolerance have been generated [21-23]. In this review, flood-response mechanisms are summarized with proteomic data with subcellular and post-translational modifications (PTMs). In addition, soybean survival under flooding, which is defined as a tolerance mechanism, is discussed with results of comprehensive analyses in soybean materials with flooding tolerance. Finally, interactions of the molecular mapping of omics data are proposed.

\section{Morphological and Physiological Effect of Flooding Stress on Soybean}

There is no doubt that flooding stress alters soybean morphology at the vegetative and reproductive stages [13]. Morphological traits, including seedling growth, hypocotyl pigmentation, plant flowering, seed filling, and aerenchyma formation, are influenced by flooding stress, leading to retarded plant growth and reduced seed yield. Along with morphological alterations, physiological events are triggered by flooding. The morphological and physiological effects of flooding on soybean are summarized in Table S1.

A plethora of findings present adverse effects of flooding on soybean growth and development within short- and long-term stress (Table S1). Overall, flooding stress suppressed elongation of radicle/root/hypocotyl and reduced root number/root surface/leaf area, leading to inhibition of plant growth [24-33]. However, the effect of flooding on fresh weight of plant and adventitious root was dependent on prolonged duration of stress and growth stage of soybean. For example, the fresh weight of soybean increased in $3 \mathrm{~h}$-flooded soybean, while it decreased with prolonged stress [29,33]. The length of adventitious root was shorter in 5-day-old soybean exposed to flooding for 3 days than untreated seedlings [34], while increased adventitious root was observed in 28-day-old soybean subjected to flooding for 21 days [24]. Furthermore, flooding slightly increased days to maturity [13] and caused severe yield loss of soybean regardless of growth stage [25,34]. In addition, formation of secondary aerenchyma was promoted by stress, which was considered as morphological acclimation of flooding stress $[15,35,36]$. These observed morphological alterations indicate the injurious effects of flooding on the agronomic traits of soybean; however, promising traits such as adventitious root and aerenchyma formation might enhance soybean flooding tolerance.

A series of cellular processes have been illustrated in soybean, including cell wall reorganization, calcium signaling, cellular metabolism, and hormone signaling (Table S1). Suppressed cell-wall lignification [37,38], cell-wall synthesis [17], as well as flooding-induced plasma membrane [39] 
contributed to cell-wall reorganization in soybean root. It was shown that calcium ion in the root tip and cotyledon was induced by flooding, and calcium-related proteins such as calreticulin and pyruvate decarboxylase, which were associated with protein folding and pyruvate catabolism, responded to flooding [40-43]. The deleterious effect of flooding was evident with cell death, which occurred in 2-day-old soybean exposed to flooding for 1 day and as long as 6 days [17,44,45]. Elucidation of cellular metabolism showed that protein metabolism [16,38,42,46,47], RNA metabolism [38,48], energy management [44,49], carbohydrate metabolism [50,51], and carbon-nitrogen flux [51-53] responded to flooding. In addition, hormone signaling coordinated with flooding response, showing that ethylene and abscisic acid (ABA) acted with protein metabolism and energy conservation [33,54-56]. It was noticeable that both calcium signaling and ABA were induced by flooding and triggered protein metabolism and energy metabolism, and protein phosphorylation was involved in the integration of calcium-ABA signaling. Therefore, a proteomic approach is beneficial to identify master regulators involved in stress signaling in soybean under flooding.

\section{Plant Omic Analysis to Understand Flood-Response Mechanisms in Soybean}

Plant omics is becoming important in the scientific community because of the urgent need to address issues facing humanity with regard to agricultural production, environmental decontamination, and ecological sustainability [57]. Proteomics has been utilized in the plant field since the beginning of the twenty century and it is still an irreplaceable approach to explore protein profiles in response to environmental stimuli [58]. As flooding sensitive legume with economic relevance in food production, progressive findings of flood-response mechanisms in soybean were achieved through proteomic analysis. Plant omics including proteomics, transcriptomics, metabolomics, as well as bioinformatics is reviewed in Table S2.

\subsection{Proteomics to Understand Flood-Response Mechanisms in Soybean}

Proteomics with crude proteins helps us to obtain proteins produced and utilized by organisms to sustain various processes required for flooding responses. To date, a series of protein profiles in flooded soybean has been acquired (Table S2). In 2- and 3-day-old soybean, protein profiles altered within a few hours of flooding, and alterations of proteins involved in calcium signaling and carbohydrate metabolism were recognized as flooding response $[41,50]$. When flooding is prolonged, cell death in root occurred and suppressed cell-wall synthesis/protein metabolism was implicated as a cause of stress injury $[17,28,31]$. Besides this, under flooding, alterations of proteins in the V2-growth stage were similar to germinating seeds, with carbohydrate consumption and programmed cell death [59]. Furthermore, it was indicated that protein synthesis, cell-wall metabolism, energy consumption, and antioxidant metabolism were conserved by the flooding response, which was regulated by a core group of proteins in soybean seedlings $[17,29,50,60]$. In addition, proteins involved in cell reorganization, secondary metabolism, and glycolysis protected flooded soybean from cell death, energy crisis, and toxic radicals, thereby promoting post-flooding recovery [30,61,62].

Based on flooding responsive maps sketched by crude proteins, subcellular proteomics has been applied to interpret events in targeted subcellular and bridge interactions within cell compartments. The progress of the flooding response acquired from subcellular proteomics in soybean is presented (Table S2). Under flooding, cell-wall metabolism was highlighted by proteomic analysis using crude proteins, and biosynthesis of jasmonic acid and ROS scavenging contributed to suppressed lignification in root including hypocotyl [37]. In the plasma membrane, proteins related to the antioxidative system, stress, and signaling played roles in protecting the cell from oxidative damage, protein degradation, and ion homeostasis under flooding [39]. Compared with cell wall and plasma membrane, more studies have focused on nuclear aspects and addressed the suppressed RNA metabolism and activated ABA signaling in response to flooding with exposure from 3 to 48 h $[37,48,54,55]$, whereas DNA repair via acceleration of poly-ADP-ribosylation and signaling transduction via interaction of RACK1 with 14-3-3 protein coped with prolonged flooding [63,64]. Energy consumption was evidenced with 
impaired electron-transport chains in mitochondria and proteins involved in the tricarboxylic acid (TCA) cycle were determined by mitochondrial proteomics in response to flooding $[65,66]$. In addition, endoplasmic reticulum proteomics implied that flooding suppressed protein synthesis and caused dysfunction of protein folding, leading to the reduction of glycoproteins [42,46]. Although these studies highlighted stress responses in specific subcellular regions, receptors for flooding have not been identified and stress signals within cells need further investigation.

PTMs regulate protein activity, localization, as well as protein-protein interactions in cellular processes, leading to elaborate regulation of plant response to environmental stimuli [67]. In soybean, PTM-mediated flooding response is illuminated with developed proteomics (Table S2). At initial flooding, hormone regulation of ethylene and ABA participated in flooding tolerance via phosphorylation of eukaryotic translation initiation $4 \mathrm{G}$, zinc finger/BTB domain-containing protein 47 , glycine-rich protein, and rRNA processing protein Rrp5 [33,55]. Flooding altered phosphorylation status through dephosphorylated proteins involved in protein folding/cell structure and phosphorylated proteins involved in energy production $[50,68]$. Besides this, glycosylation and ubiquitination play roles in protein synthesis and degradation under flooding. For example, a 2-day flood inhibited the biosynthesis of glycoproteins [42], while it activated ubiquitin-mediated protein degradation [16]. Under flooding, $S$-nitrosylation proteins were enriched in glycolysis and fermentation, and S-nitrosylation modulated the stress response via activated or deactivated forms of sugar-degrading enzymes [69]. Collectively, these findings indicate that protein phosphorylation is an initial response to flooding and it modulates protein synthesis and RNA processing; however, glycosylation, ubiquitination, and $S$-nitrosylation modulate protein metabolism, carbohydrate catabolism, and energy production in soybean with extended stress duration.

\subsection{Plant Omics of Transcriptomics, Metabolomics, and Bioinformatics}

Plants respond to stressful conditions through changes in omic profiles and enormous progress has been achieved in the area of plant omics [18]. Current findings of transcriptomics, metabolomics as well as bioinformatics collected from flooded soybean are summarized in Table S2. More than 6000 genes were identified in the root and hypocotyl of soybean exposed to flooding for 6 and $12 \mathrm{~h}$, and downregulated genes of pyrophosphate dependent on phosphofructokinase and upregulated genes encoding small proteins played roles in flooding acclimation [70]. In the leaf, 3498 differentially expressed genes were identified, and genes involved in cell-wall precursors and starch content served as adaptive mechanisms for soybean survival from flooding [71]. Tamang et al. [72] reported that although the expression of organ-specific genes was demanded in different organs of soybean exposed to submergence, conserved responses were invoked in shoot and root. These documents indicate that carbohydrate catabolism might play a conserved role in flooded soybean regardless of plant organs. Furthermore, flooding disturbed the balance of the carbon-nitrogen ratio in soybean root, which was evident with accumulated GABA and increased metabolites involved in the TCA cycle $[52,65]$. Although carbohydrate catabolism and carbon-nitrogen influx were pointed out by transcriptomic and metabolomic studies of flooded soybean, reference maps of protein profiles were sketched using proteomics data stored in the Soybean Proteome Database [73-75]. The database was not a simple tank for data storage; however, multiple ome data were acquired from uniform experimental conditions. Moreover, the Soybean Proteome Database provided temporal profiles of omes, which were characterized with unified temporal-profile tags. Although proteomic data were collected from gel-based proteomic studies at the beginning, the database gradually updated with the information of gel-free proteomics, subcellular proteomics, PTMs profiles, protein categorization, and protein-protein interactions from different organs in flooded soybean. Therefore, the Soybean Proteome Database has provided comparative and integrated omes in soybean, assisting in the illustration of flood-response and -tolerance mechanisms in soybean. 


\subsection{The State of Proteomic Analysis of Other Crops under Flooding Stress}

A considerable volume of proteomic studies of flooding response focuses on soybean, while works on other crops such as rice [76-78], maize [79-82], wheat [83-86], rapeseed [87], barley [88], and alfalfa [89] are collected in Table 1, which assists in addressing the commonality of flooding response in crops. ROS serves as an intermediator to percept environments during seed imbibition and ROS levels are maintained at a level which triggers cellular events associated with germination [90]. During seed germination, proteins related to redox were enriched, with decreased abundance in anoxic rice coleoptile [76] and elevation of hydrogen peroxide was a component of the pathway that induced alcohol dehydrogenase expression under low oxygen [91], indicating that ROS acted as a signaling molecule in alcohol fermentation. It was noticeable that phenylpropanoid biosynthesis and fatty acid metabolism were ubiquitous stress responses to drought, salinity, and submergence during seed germination in wheat; however, starch and sucrose metabolism was indicated as a submergence-specific response for germination [86]. Whether crops could prepare for the second round of flooding stress was examined and it was showed that waterlogging priming alleviated the yield loss of wheat through ethylene signaling, which improved leaf photosynthesis by promoting stomata opening under waterlogging [84]. Similar to the flooding response in soybean, cellular events such as electron transfer chain, programmed cell death, energy metabolism, ethylene production, and cell-wall hydrolysis were induced by flooding in other crops, indicating that these metabolisms were conserved by flooding responses within crop species. Currently, subcellular proteomics, PTMs, as well as post-flooding responses are rarely considered in other crops, and thus proteomic studies in soybean could be used to unveil molecular mechanisms underlying the core metabolism in different crops towards flooding stress.

Table 1. Utilization of proteomics in other crops under flooding stress.

\begin{tabular}{|c|c|c|c|c|}
\hline Crop & Organ & $\begin{array}{l}\text { Growth Stage/ } \\
\text { Flooding Time }\end{array}$ & Findings & Reference \\
\hline & coleoptile & seed/4 days & $\begin{array}{l}\text { The majority of identified proteins were related } \\
\text { to stress response and redox metabolism in } \\
\text { anoxic rice coleoptile. }\end{array}$ & [76] \\
\hline rice & spike & $\begin{array}{l}57-\text { day-old } / 8 \\
\text { days }\end{array}$ & $\begin{array}{l}\text { Electron transfer chain was destroyed to inhibit } \\
\text { photosynthesis, while antioxidant system was } \\
\text { activated to regulate ROS metabolism under } \\
\text { submergence stress. }\end{array}$ & [77] \\
\hline \multirow{4}{*}{ maize } & leaf & $\begin{array}{l}\text { 4-leaf-stage/5 } \\
\text { days }\end{array}$ & $\begin{array}{l}\text { Proteins related to energy metabolism, } \\
\text { photosynthesis, PCD, phytohormone, and } \\
\text { polyamine responded to flooding; and } \\
\text { damaged photosynthetic system led to } \\
\text { disruption in energy metabolism and ROS } \\
\text { overproduction under flooding. }\end{array}$ & [79] \\
\hline & root & $\begin{array}{l}\text { 2-leaf-stage/3 } \\
\text { days }\end{array}$ & $\begin{array}{l}\text { NADP-malic enzyme, glutamate } \\
\text { decarboxylase, coproporphyrinogen III oxidase, } \\
\text { GSH S-transferase, GSH dehydrogenase, and } \\
\text { XTH } 6 \text { were specifically accumulated to } \\
\text { manage energy consumption, maintain pH } \\
\text { levels, and minimize oxidative damage in } \\
\text { waterlogging-tolerant maize. }\end{array}$ & [80] \\
\hline & leaf & $\begin{array}{l}\text { 29-day-old/4, } \\
28,52 \mathrm{~h}\end{array}$ & $\begin{array}{l}\text { Combination of native IEF-PAGE and hrCNE } \\
\text { was powerful to investigate alteration of Class } \\
\text { III peroxidases, which played roles in ROS } \\
\text { scavenging, cell-wall loosening, and } \\
\text { aerenchyma formation in flooded maize. }\end{array}$ & [81] \\
\hline & leaf & $\begin{array}{l}\text { 3-leaf-satge/6 } \\
\text { days }\end{array}$ & $\begin{array}{l}\text { 6-BA exaggerated waterlogging defense } \\
\text { through proteins related to protein metabolism, } \\
\text { ROS scavenging, and fatty acid metabolism. }\end{array}$ & [82] \\
\hline
\end{tabular}


Table 1. Cont.

\begin{tabular}{|c|c|c|c|c|}
\hline Crop & Organ & $\begin{array}{l}\text { Growth Stage/ } \\
\text { Flooding Time }\end{array}$ & Findings & Reference \\
\hline \multirow{4}{*}{ wheat } & root & $\begin{array}{l}\text { 2-day-old/2 } \\
\text { days }\end{array}$ & $\begin{array}{l}\text { Decreased proteins of methionine synthase, } \\
\text { beta-1,3-glucanases, and beta-glucosidase } \\
\text { played roles in methionine assimilation and } \\
\text { cell wall hydrolysis under flooding. }\end{array}$ & [83] \\
\hline & leaf & $\begin{array}{l}7 \text { days after } \\
\text { anthesis/7 days }\end{array}$ & $\begin{array}{l}\text { Waterlogging priming induced proteins related } \\
\text { to energy metabolism, stress defense, and } \\
\text { ethylene biosynthesis to improve wheat } \\
\text { tolerance towards waterlogging. }\end{array}$ & [84] \\
\hline & root & $\begin{array}{l}\text { 12-day-old/1-3 } \\
\text { days }\end{array}$ & $\begin{array}{l}\text { Acid phosphatase, oxidant protective enzyme, } \\
\text { and SAM1 could be utilized as indicators for } \\
\text { improving waterlogging tolerance in wheat. }\end{array}$ & [85] \\
\hline & radicle & seed/1 day & $\begin{array}{l}\text { Starch-sucrose metabolism was specifically } \\
\text { enriched by submergences compared with salt } \\
\text { and drought during seed germination. }\end{array}$ & [86] \\
\hline rapeseed & root & $\begin{array}{l}\text { 1.5-day-old } / 4,8, \\
12 \mathrm{~h}\end{array}$ & $\begin{array}{l}\text { Flooding induced proteins were mainly } \\
\text { enriched in oxidation-reduction process, signal } \\
\text { transduction, carbohydrate metabolism } \\
\text { regardless of rapeseed genotype; however, } \\
\text { large number of flood-altered-proteins } \\
\text { indicated a quick active proteome response in } \\
\text { the tolerant cultivar. }\end{array}$ & [87] \\
\hline barley & root, leaf & $\begin{array}{l}\text { 4-leaf-stage/21 } \\
\text { days }\end{array}$ & $\begin{array}{l}\text { Proteins of PDC, ACO, and GST played roles in } \\
\text { energy metabolism, ethylene production, and } \\
\text { ROS homeostasis to improve waterlogging } \\
\text { adaptation. }\end{array}$ & [88] \\
\hline alfalfa & leaf & $\begin{array}{l}\text { 35-day-old/12 } \\
\text { days }\end{array}$ & $\begin{array}{l}\text { Amylase, ERF, CIPKs, GPX, and GST conferred } \\
\text { alfalfa waterlogging tolerance. }\end{array}$ & [89] \\
\hline
\end{tabular}

6-BA, 6-benzyladenine; ACO, 1-amino cyclopropane 1-carboxylic acid oxidase; CIPK, calcineurin B-like interacting protein kinase; ERF, ethylene response factor; GPX, glutathione peroxidase; GS, glutamine synthetase; GSH, glutathione; GST, glutathione-S-transferase; hrCNE, high resolution Clear Native Electrophoresis; IEF, isoelectric focusing; PAGE, polyacrylamide gel electrophoresis; PCD, programmed cell death; PDC, pyruvate decarboxylase; ROS, reactive oxygen species; SAM1, S-adenosylmethionine synthetase $1 ; \mathrm{XTH}$, xyloglucan endotransglucosylase. Publications from 2010 onwards on crop proteomics under flooding stress were collected.

\section{Proteomic Analysis to Understand Flood-Tolerant Mechanisms in Soybean}

Narrow genetic background and limited genetic diversity restrict the development of new elite soybean cultivars; however, man-made mutations produce numerous genetic variations which could be used to select lines with ideal plant architecture and tolerant characteristics [92]. Besides traditional germplasm screening, several approaches are adopted to promote soybean growth under flooding, such as transgene technology, millimeter-wave irradiation, and chemical supplication of phytohormone, plant-derived smoke, and nanoparticles (NPs). As a cutting-edge molecular technique, the application of proteomics on flood-tolerant crops was reviewed, reinforcing its potential roles to assist in developing high-yield flood-tolerant materials under flooding [22]. Elucidations of proteomics on flood-tolerant mechanisms in soybean are outlined in Table 2. 
Table 2. Proteomic analysis to understand flood-tolerant mechanisms in soybean.

\begin{tabular}{|c|c|c|c|}
\hline Experimental Materials & $\begin{array}{l}\text { Growth Stage/ } \\
\text { Flooding Time }\end{array}$ & Findings & Reference \\
\hline $\begin{array}{l}\text { radicle/128 soybean } \\
\text { cultivars }\end{array}$ & 2-day-old/2 days & $\begin{array}{l}\text { Levels of RNA-metabolism related } \\
\text { proteins and flooding indicator proteins } \\
\text { correlated with flooding tolerance levels } \\
\text { in soybean. }\end{array}$ & [31] \\
\hline root/flooding mutant & 2-day-old/2 days & $\begin{array}{l}\text { Anaerobic metabolism was more } \\
\text { efficient in mutant line than wild-type } \\
\text { soybean under flooding, and reduction } \\
\text { of cell-wall loosening allowed rapid } \\
\text { growth of root tip after water removal. }\end{array}$ & [44] \\
\hline $\begin{array}{l}\text { root, hypocotyl/ } \\
\text { GmAdh2-overexpressed } \\
\text { soybean }\end{array}$ & 2-day-old/2 days & $\begin{array}{l}\text { Overexpression of GmAdh2 induced } \\
\text { alternation of carbon flow with } \\
\text { glycolysis and alcohol fermentation, } \\
\text { improving germination under flooding. }\end{array}$ & [93] \\
\hline $\begin{array}{l}\text { root, hypocotyl/ } \\
\text { millimeter-wave } \\
\text { treatment }\end{array}$ & 2-day-old/2 days & $\begin{array}{l}\text { Millimeter-wave irradiation promoted } \\
\text { soybean recovery from flooding via } \\
\text { regulation of glycolysis and } \\
\text { redox-related pathways. }\end{array}$ & [94] \\
\hline root/ABA treatment & 2-day-old/2 days & $\begin{array}{l}\text { ABA conferred soybean flooding } \\
\text { tolerance through regulation of } \\
\text { glycolysis and nuclear-localized } \\
\text { proteins of zinc finger proteins, cell } \\
\text { division cycle } 5 \text {, and transducin. }\end{array}$ & [54] \\
\hline \multirow{2}{*}{$\begin{array}{l}\text { root, hypocotyl/ } \\
\text { smoke treatment }\end{array}$} & $\begin{array}{l}\text { 2-day-old/2-day } \\
\text { flood followed by } \\
\text { 4-day recovery }\end{array}$ & $\begin{array}{l}\text { Smoke enhanced soybean recovery } \\
\text { from flooding via regulation of } \\
\text { carbohydrate metabolism, glycolysis, } \\
\text { and cell-wall components. }\end{array}$ & [95] \\
\hline & 2-day-old/2 days & $\begin{array}{l}\text { Smoke promoted root growth of } \\
\text { flooded soybean via energy production, } \\
\text { ROS scavenging, activated ornithine } \\
\text { synthesis, and suppressed } \\
\text { ubiquitin proteasome. }\end{array}$ & {$[96,97]$} \\
\hline $\begin{array}{l}\text { root, leaf } / \mathrm{Al}_{2} \mathrm{O}_{3^{-}}, \mathrm{ZnO}- \\
\text { Ag-NPs treatment }\end{array}$ & 7-day-old/3 days & $\begin{array}{l}\text { Abundance of proteins involved in } \\
\text { oxidation-reduction, stress signaling, } \\
\text { and hormone pathway was principal } \\
\text { for optimum growth of soybean under } \\
\text { flooding in presence of Ag-NPs } \\
\text { compared with } \mathrm{Al}_{2} \mathrm{O}_{3} \text { - and } \mathrm{ZnO}-\mathrm{NPs} \text {. }\end{array}$ & [98] \\
\hline \multirow{2}{*}{$\begin{array}{l}\text { root, } \\
\text { hypocotyl/ } \mathrm{Al}_{2} \mathrm{O}_{3}-\mathrm{NPs} \\
\text { treatment }\end{array}$} & $\begin{array}{l}\text { 2-day-old/1, 2, 3, } 4 \\
\text { days }\end{array}$ & $\begin{array}{l}\mathrm{Al}_{2} \mathrm{O}_{3}-\mathrm{NPs} \text { facilitated soybean } \\
\text { acclimation to flooding via limited cell } \\
\text { death, activated aerobic pathway, and } \\
\text { ascorbate glutathione pathway. }\end{array}$ & {$[99,100]$} \\
\hline & $\begin{array}{l}\text { 2-day-old/2-, 4-day } \\
\text { flood followed by 2- } \\
\text { and 4-day recovery }\end{array}$ & $\begin{array}{l}\mathrm{S} \text {-adenosyl-L-methionine-dependent } \\
\text { methyltransferases and enolase were } \\
\text { associated with flooding recovery in } \\
\text { presence of } \mathrm{Al}_{2} \mathrm{O}_{3} \text {-NPs. }\end{array}$ & [101] \\
\hline \multirow{2}{*}{$\begin{array}{l}\text { root, cotyledon/Ag-NPs } \\
\text { treatment }\end{array}$} & 2-day-old/2, 4 days & $\begin{array}{l}\text { Under flooding, chemically synthesized } \\
\text { Ag-NPs shifted fermentation to normal } \\
\text { cellular process, while biosynthesized } \\
\text { Ag-NPs enhanced protein degradation } \\
\text { and ATP content. }\end{array}$ & [102-104] \\
\hline & 2-day-old/2 days & $\begin{array}{l}\text { Mixture of Ag-NPs, nicotinic acid, and } \\
\mathrm{KNO}_{3} \text { exerted positive effect on } \\
\text { soybean growth under flooding } \\
\text { through regulation of protein quality } \\
\text { control of misfolded proteins in the ER. }\end{array}$ & [45] \\
\hline
\end{tabular}

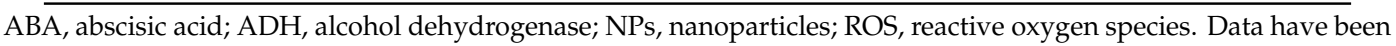
collected from 2010 to 2020 . 


\subsection{Proteomics Using Generated Flood-Tolerant Lines/Varieties}

\subsubsection{Soybean Varieties with Flooding Tolerance}

Bottlenecks in genetic diversity challenge germplasm screening for flood-tolerant lines of soybean, while comparative proteomics assists in the elucidation of flooding tolerance in soybean. Nanjo et al. [31] examined the flood-tolerant index of 128 soybean varieties, including survival rate of plant, lateral root development, radicle elongation, and symptoms of flooding injury; these varieties were classified into three categories based on the index. Proteomic study of the soybean radicle collected from these categories showed that RNA binding/processing-related proteins and flooding stress indicator proteins correlated with flood-tolerant index [31]. Lin et al. [105] reported that Qihuang 34 was a flood-tolerant cultivar, which was indicated with the highest survival ratio of seedling, and metabolic pathways relevant to carbon metabolism, mitogen-activated protein kinase signaling, fatty acid degradation, as well as isoflavonoid biosynthesis were enriched via differently changed genes and proteins under flooding. In addition, it was shown that glycolysis was activated for ATP production for plant survival; however, decreased lignin caused plant softening under submergence for a long period of time [105]. These findings are consistent with master regulations of RNA metabolism and carbohydrate supply in flooded soybean that were discussed above. In addition, this raises the possibility that secondary metabolites might improve flooding tolerance as for isoflavonoid.

\subsubsection{Mutant Soybean with Flooding Tolerance}

Deepwater- and submergence-tolerant rice utilize the strategy of internode elongation or remain stunted to survive flooding stress [8]. Zaman et al. [106] found contrasting tolerant mechanisms in pea seed at germination stage under waterlogging, including a quiescence strategy where the seed reserved the energy preserved and used an escape strategy involving rapid germination utilizing energy from protein/lipid metabolism. To characterize flood-tolerant mechanisms in soybean, a flood-tolerant line was generated by physical mutagenesis of gamma-ray irradiation with six-time tolerant screening [44]. Proteomic analysis using the flood-tolerant mutant indicated that proteins involved in cell-wall loosening did not increase in the mutant compared with wild-type soybean, thereby preserving the viability of the root tip and permitting its rapid growth during the post-flooding stages [44]. Due to the oxygen-depleted environment arising from flooding, a crisis in ATP availability occurred [107]; however, to manage the energy crisis, the balance of glycolysis aided in soybean survival from submergence $[38,105]$ and enhanced fermentation was necessary for the acquisition of flooding tolerance [44]. These findings indicate that activated fermentation and glycolysis confer soybean flooding tolerance to ensure survival. In addition, carbohydrate catabolism might be helpful to build blocks for cell-wall synthesis in a flood-tolerant mutant.

\subsubsection{Transgenic Soybean Overexpressed Flood-Response Gene}

Biotechnology of genome editing is an ideal approach for precision crop breeding; however, there are no reports of its application to the improvement of flooding tolerance in crops. Transgenic approaches have been widely used to address flood-tolerant mechanisms in Arabidopsis [108,109], rice [110], maize [111], and soybean [93]. Under flooding, soybean with heteroexpression of AtXTH31 presented higher germination rates and longer length of seedling than the wild type, indicating that AtXTH31 conferred soybean flooding tolerance [112]. Moreover, transcript levels of the XTH gene family in soybean were investigated and $23 \mathrm{GmXTH}$ were significantly regulated by ethylene in soybean root, indicating that ethylene played a role in $\mathrm{GmXTH}$-mediated cell-wall remodeling under flooding [112]. GmAdh2 was identified as a root-specific gene in response to flooding, and thinner hypocotyl as well as smaller area of primary leaf were observed in wild-type soybean compared with GmAdh2-overexpressed lines, indicating that GmAdh2-mediated fermentation contributed to the acquisition of flooding tolerance $[93,113]$. This limited volume of studies indicates that remodeling 
root architecture and enhanced anaerobic respiration are feasible to improve soybean tolerance to flooding stress.

\subsubsection{Soybean Irradiated with Millimeter Wave}

Millimeter waves are typically defined to lie within a frequency of 30-300 GHz and millimeter-wave radiation is an environmentally friendly technology which has been proposed as a useful method to increase the quality characteristics and harvest for agricultural plants [114,115]. Betskii et al. [115] found the main results of millimeter-wave irradiation on plants with considerably increased energy of germination, seed germination rates, and short periods of phenophases. Zhong et al. [94] examined the action of irradiated-millimeter wave on soybean, indicating that irradiation elongated the hypocotyl of soybean without and with flooding. It was reported that soybean seeds pretreated with millimeter-wave irradiation presented promoted growth under oxidative stress arising from flooding through the regulation of activated sugar metabolism and enhanced ascorbate/glutathione metabolism [94]. In addition, radiation altered the intracellular structures of lipoproteins, mitochondria, and microsomes [115]; however, flooding caused lipid peroxidation and mitochondrial impairment in soybean $[65,72]$. Collectively, these results indicate that seed priming with millimeter-wave irradiation is feasible to improve soybean performance under flooding, which might modulate redox scavenging in plant cells, especially in mitochondria.

\subsection{Application of Chemicals for Flooding Tolerance}

\subsubsection{Abscisic Acid Treatment}

Flooding causes the rapid accumulation of ethylene in plant cells, and ethylene-mediated response assists in flooding acclimation through ethylene response factor, ROS, sugar, and nitric oxide [116]. It was reported that accumulated ethylene stimulated petiole elongation through inhibiting the biosynthesis of $\mathrm{ABA}$, indicating contrasting interactions between ethylene and $\mathrm{ABA}$ in flood-tolerant Rumex palustris [117]. However, Hwang and Vantoai [118] found that ABA enhanced the anoxic survivability of maize seedling to $87 \%$ through the activated synthesis of new proteins and increased enzyme activity of alcohol dehydrogenase. Under flooding, the content of endogenous ABA was lower in waterlogging-tolerant soybean than susceptible lines, indicating better development of aerenchyma cells in tolerant lines than in sensitive plants [119]. The contribution of exogenous ABA to soybean flooding tolerance was investigated by proteomics. It was shown that proteins involved in glycolysis, vesicle transport, and cell organization decreased under flooding in the presence of ABA; however, endogenous ABA enhanced flooding tolerance through the control of energy conservation via the glycolytic system [54]. These results indicate that although ABA treatment might suppress the formation of aerenchyma cells, energy conservation by controlling sugar metabolism is the major strategy utilized by soybean for survival from flooding stress.

\subsubsection{Plant-Derived Smoke Treatment}

Smoke derived from burning-plant materials and smoke treatment improved seed germination and plant tolerance to abiotic stresses [120-122]. In soybean, smoke treatment increased the length of flooded seedlings and recovered the inhibited effect of flooding after water removal $[95,96]$. Proteomic studies showed that the metabolisms of energy production and ROS scavenging contributed to tolerance towards flooding, while processes of carbohydrate metabolism and cell-wall synthesis assisted in plant growth during the post-recovery stage [95,97]. Zhong et al. [96] found that smoke treatment improved soybean growth through the regulation of nitrogen-carbon transformation via ornithine synthesis and protein degradation via ubiquitin proteolysis under flooding. Study of maize radicle at the onset of smoke treatment showed that smoke responsive genes between stress- and ABA-related genes were overrepresented, indicating that smoke might play similar roles to ABA in plant acclimation to unfavorable environments [120]. Furthermore, the structure of karrikins was similar to the D-ring of 
strigolactones and they shared signaling pathways during plant development, which acted in parallel to regulate MAX2 activity in a ligand-dependent manner $[123,124]$. Taken together, these findings indicate that smoke treatment enables soybean tolerance against flooding stress; however, the involvement of smoke-induced signal transduction and the interaction between $\mathrm{ABA}$ and strigolactones in response to flooding need clarification.

\subsubsection{Nanoparticle Treatment}

NPs are typically ultrafine particles with sizes of less than $100 \mathrm{~nm}$ with increasing application in the agricultural sector due to rapid developments in nanotechnology $[99,125]$. Previously, NPs were considered pollutants with toxicity for soybean growth [98]; however, increasing evidence indicates the positive roles of NPs on flooded soybean [100-104]. $\mathrm{Al}_{2} \mathrm{O}_{3}-\mathrm{NPs}$ promoted the growth of flooded soybean through controlling energy metabolism and cell death [100]; however, Ag-NPs shifted the metabolism from the fermentative pathway towards normal cellular processes under hypoxia conditions [102,103]. Yasmeen et al. [101] reported that $\mathrm{Al}_{2} \mathrm{O}_{3}-\mathrm{NPs}$ increased the survival percentage of soybean recovered from flooding through the regulation of $S$-adenosyl-L-methionine-dependent methyltransferases and enolase, indicating that modification of methylation and glycolysis aided in soybean recovery from prolonged stress. Actions of NPs on plant growth are largely dependent on size, concentration, and stability. For example, soybean growth was improved by biosynthesized Ag-NPs compared with chemically synthesized Ag-NPs [104]. With regard to flooding-mediated energy metabolism, $\mathrm{Al}_{2} \mathrm{O}_{3}$-NPs with sizes of $30-60 \mathrm{~nm}$ played positive roles; however, particles of 5 and $135 \mathrm{~nm}$ posed negative effects, indicating that $\mathrm{Al}_{2} \mathrm{O}_{3}-\mathrm{NPs}$ with various sizes affected the membrane permeability of mitochondria and the activity of the TCA cycle [99]. In addition, soybean treated with a mixture of Ag-NPs, nicotinic acid, and $\mathrm{KNO}_{3}$ displayed better growth than that treated with Ag-NPs alone, which was through regulation of activated protein quality control for misfolded proteins [45]. Collectively, these results indicate that NP treatment promotes soybean survival from flooding mainly through maintaining mitochondria function, which could alleviate the energy shortage and lipid oxidation induced by flooding stress.

\subsection{Omic Analysis Using Flooding-Tolerant Materials}

Plant omics of transcriptomics, proteomics, and metabolomics provides further insights into the inner workings of plant cells, cell-cell communications, and plant-environment interactions [57]. It was shown that genes related to protein folding and RNA modification were associated with the improvement of flooding tolerance, which was evidenced with transcriptomic analysis in Qihuang 34 [105] and Embrapa 45 [126], which are flood-tolerant soybean cultivars. Similar results were obtained from proteomic studies using flood-tolerant materials of mutant and ABA-treated seedlings, showing that protein synthesis and RNA regulation-related proteins triggered soybean tolerance to initial flooding [38]. Together with RNA regulation and protein metabolism, hormone response contributed to initial flooding tolerance through the inhibition of cytochrome P450 77A1 [127]. Moreover, metabolomic study of soybean showed that most altered compounds were enriched in carbon-nitrogen metabolism and phenylpropanoid pathway, and especially an increased level of sucrose was observed in flooding-sensitive cultivars than in tolerant cultivars [128]. Integrated omic data derived from proteomics and metabolomics indicated that fructose was a critical metabolite to assist in soybean flooding tolerance at initial stages via regulation of hexokinase and phosphofructokinase [51]. Taken together, proteomics, in combination with transcriptomics and metabolomics, improves the capability to uncover prospective flood tolerance responses in soybean as for RNA modification, protein synthesis, and sugar catabolism.

\section{Differences between Response and Tolerant Mechanisms against Flooding Stress}

Flooding response within stress and during the post-recovery stage as well as flood tolerance at the initial stage were characterized in soybean based on proteomics $[20,22,23]$. With the integration of 
plant omics data, which were collected from uniform experimental conditions, a schematic of flooding response and tolerance in soybean root is presented in Figure 1.

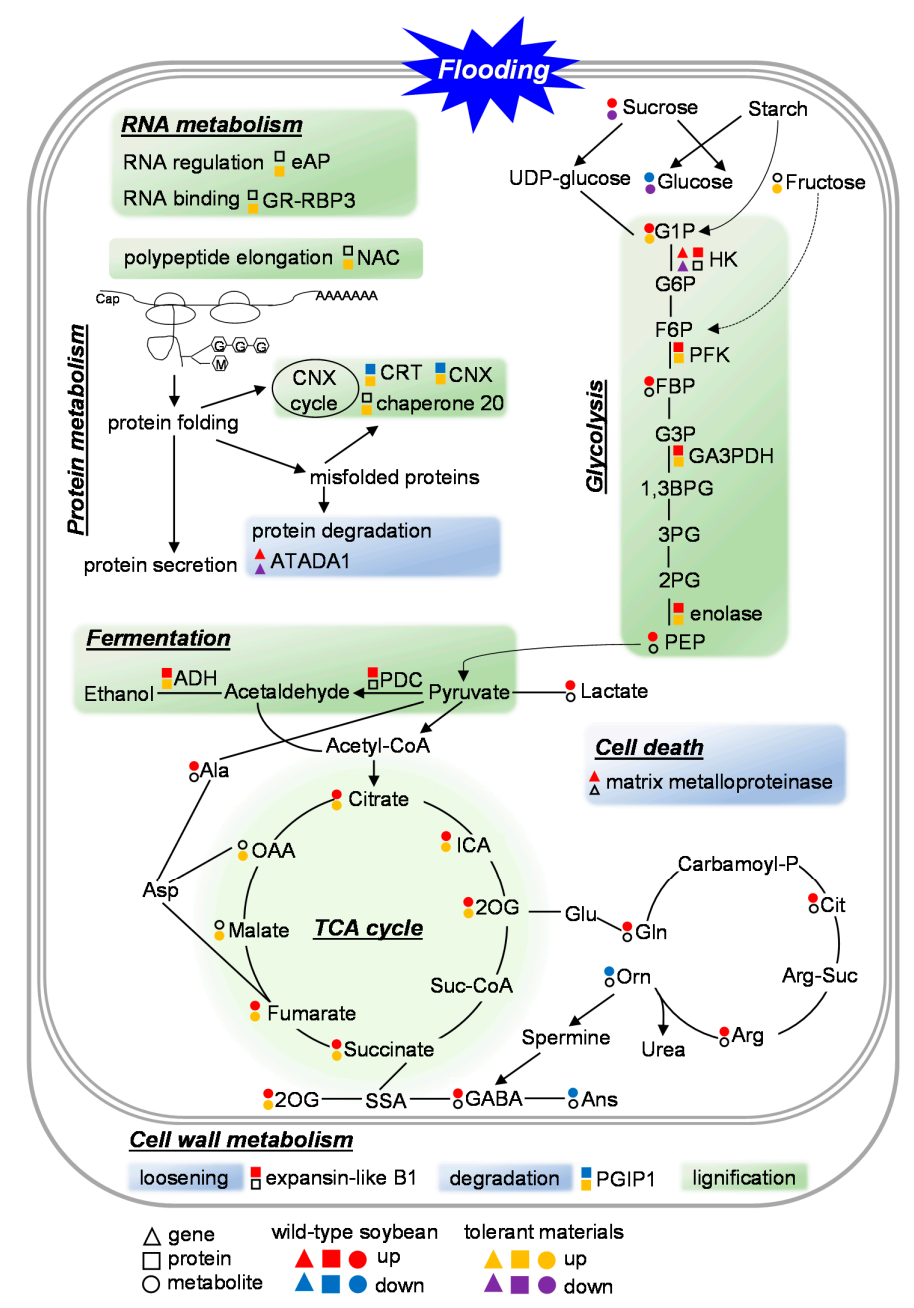

Figure 1. Differences between response and tolerant mechanisms against flooding stress. Scheme of core cellular pathways between response and tolerance in root of early-stage soybean in response to flooding stress is summarized based on plant omics data collected from wild-type soybean and flood-tolerant materials. Triangle, box, and circle indicate gene, protein, and metabolite, respectively. Red and blue colors indicate up- and down-regulation of gene/protein/metabolite in flooded wild-type soybean compared with untreated plant, respectively. Orange and purple colors indicate up- and down-regulation of gene/protein/metabolite in flood-tolerant materials compared with wild-type soybean under flooding, respectively. Gene, protein, and metabolite in black color mean the alteration induced by flooding stress is not clear. Green and blue colors indicate activation and suppression of metabolism in flood-tolerant materials compared with wild-type soybean under flooding. Abbreviations: 1,3BPG, glycerate 1,3-bisphosphate; 2OG, 2-oxoglutarate; 2PG, 2-phospho-glycerate; 3PG, 3-phospho-glycerate; ADH, alcohol dehydrogenate; Ala, alanine; Ans, anserine; Arg, arginine; Arg-Suc, arginino-succinate; Asp, aspartic acid; ATADA1, ATPase family AAA domain containing protein 1; Cit, citrulline; CNX, calnexin; CRT, calreticulin; eAP, eukaryotic aspartyl protease; FBP, fructose 1,6-bisphosphate; G, glucose; G1P, glucose 1-phosphate; G3P, glyceradehyde 3-phosphate; G6P, glucose 6-phosphate; GA3PDH, glyceraldehyde 3-phosphate dehydrogenase; GABA, gamma-aminobutyric acid; Gln, glutamine; Glu, glutamic acid; GR-RBP3, glycine-rich RNA-binding protein 3; HK, hexokinase; ICA, isocitrate; $\mathrm{M}$, mannose; NAC, nascent polypeptide-associated complex; OAA, oxaloacetate; Orn, ornithine; PGIP1, polygalacturonase-inhibiting protein 1; PDC, pyruvate decarboxylase; PEP, phosphoenopyruvate; PFK, phosphofructokinase; SSA, succinate semialdehyde; Suc-CoA, succinyl-coenzyme A. 
RNA metabolism plays a role in flooding tolerance, which was indicated by increased protein abundance and upregulated transcript levels of eukaryotic aspartyl protease and glycine-rich RNA-binding protein 3 in flood-tolerant materials compared with wild-type soybean [38]. Proteases participated in protein quality control, protein degradation, and cell lysis in response to environmental stimuli [129]. It was reported that overexpression of AtASPG1, an aspartic protease gene, enhanced drought tolerance and it functioned in ABA-dependent pathways in Arabidopsis [130]. Furthermore, AtASPG1 localized in the endoplasmic reticulum, indicating its possible roles in protein processing [130]. A glycine-rich RNA-binding protein 3 was cloned from cucumber fruit, namely CsGR-RBP3, and Arabidopsis overexpressed CSGR-RBP3 displayed lower ROS levels and faster growth under chilling stress [131]. Moreover, CsGR-RBP3 localized in the mitochondria and its expression level was downregulated by ABA biosynthesis inhibitor [131]. These results indicate that eukaryotic aspartyl protease and glycine-rich RNA-binding protein 3 improve soybean flooding tolerance by regulating protein metabolism and ROS scavenging. In addition, it suggests that the endoplasmic reticulum and mitochondria might be susceptible to flooding.

Protein metabolism was shown to trigger flooding tolerance in soybean, and proteins including nascent polypeptide associated complex, chaperone proteins, as well as ATPase family AAA domain containing protein 1 were relevant to protein synthesis, folding, and degradation $[38,42,45,127]$. Nascent polypeptide associated complex accumulated in flood-tolerant materials compared with wild-type plants in response to initial flooding [38]. It interacted with polypeptides and worked as an integral component for protein folding, which occurred in the calnexin cycle with the help of an array of chaperone proteins [132]. In the calnexin cycle, chaperones of calnexin, calreticulin, and chaperone 20 increased in flood-tolerant materials [38,45]; however, inhibition of the calnexin cycle in flooded wild-type plants accelerated the accumulation of misfolded proteins, thereby promoting protein degradation. Degradation of misfolded proteins is critical to reestablish homeostasis equilibrium for protein metabolism [133]. It was reported that ubiquitin-mediated proteolysis was activated in flooded wild-type soybean [16], while the transcript level of ubiquitination-related protein ATPase family AAA domain containing protein 1 was downregulated in flood-tolerant materials [127]. Collectively, this indicates that enhanced polypeptide synthesis and protein folding lighten the load of misfolded proteins, ultimately ensuring the high efficiency of protein quality control under flooding.

A consequence of flooding stress is the requirement for energy conservation, which is invoked through adjustments in gene expression, carbohydrate catabolism, $\mathrm{NAD}(\mathrm{P})^{+}$regeneration, and ATP production [107]. Imbalance of carbohydrate metabolism was associated with flooding injury in wild-type soybean [50], and protein abundance of phosphofructokinase [51], glyceraldehyde-3-phosphate dehydrogenase [53], as well as enolase [38] was further accelerated in flood-tolerant materials compared with wild type. Under flooding, down-regulated hexokinase and enhanced glycolysis were observed in flood-tolerant materials compared with wild type [23,51]. Besides this, glucose degradation and sucrose accumulation were accelerated in flooded wild-type soybean [50]; however, contents of sucrose and glucose were reduced in flood-tolerant materials [51]. Pyruvate is the end metabolite of glycolysis, and it enters fermentation and the TCA cycle for ATP generation. With regard to fermentation, increased alcohol dehydrogenase in flooded wild-type soybean was further accumulated in flood-mutant lines [44,50], and overexpression of GmAdh2 conferred soybean flooding tolerance [93]. It was shown that metabolites involved in the TCA cycle that were induced by flooding were further accumulated in flood-tolerant materials [51,52]. Moreover, under flooding, ATP production derived from the TCA cycle was reduced [65]; however, the TCA cycle was enhanced in flood-tolerant materials compared with wild type [53]. Taken together, these results imply that soybean copes with energy crisis from flooding stress by relying on the activation of glycolysis, fermentation, and the citrate cycle.

Cell-wall architecture enables plants' adaptation to environmental stimuli. Flooding suppressed cell-wall lignification in wild-type soybean; however, it was recovered in flood-tolerant materials [38]. Besides this, flooding induced alterations of proteins associated with cell-wall metabolism in 
soybean. For example, expansin-like B1-like proteins, which were considered as flooding injury-associated indicators, accumulated depending on flooding severity [17]; however, they did not change in flood-tolerant materials [38]. Expansins played roles in cell-wall loosening and overexpression of NtEXP4 conferred tobacco tolerance to salt and drought stresses [134]. Polygalacturonase-inhibiting protein 1 was another cell-wall-related protein, and it dramatically accumulated in flood-tolerant materials compared with wild-type soybean under flooding [38]. It was reported that polygalacturonase-inhibiting proteins inhibited fugal polygalacturonases, which degraded cell-wall pectin and caused cell-wall degradation [135]. Moreover, up-regulated polygalacturonases played roles in the programmed cell death of root cortical cells in maize under waterlogging [136]. Therefore, it was indicated that accumulated polygalacturonase-inhibiting protein 1 might suppress cell-wall degradation and eliminate cell death. Under flooding, cell death was an extensive injury in soybean root [17]; however, it was less evident in the flood-tolerant line than wild-type soybean [44]. In addition, Yin et al. [127] reported that matrix metalloproteinase was responsible for cell death and it was down-regulated in flood-tolerant materials compared to wild-type soybean. Taken together, these results indicate that reinforcement of cell-wall plasticity and cell-wall thickening improve soybean adaption to flooding stress.

Current developments in soybean omics provide the capability to identify genes, proteins, metabolites, as well as metabolic pathways that are associated with flooding response and tolerance, which were discussed above. Integrated omic data pointed out the core set of metabolic pathways in flooded soybean, including RNA metabolism, protein metabolism, carbohydrate metabolism, cell wall metabolism, and cell death (Figure 2). Consistent with these findings in flooded soybean, it was suggested that under flooding, the most promising traits related to morphological adaptations included enhanced root porosity, a barrier against radial oxygen loss, and the formation of adventitious roots; however, metabolic adaptations were related to the antioxidant system and carbohydrate availability [137]. The whole genome sequence of soybean Williams 82 was available in 2010 [138], which facilitated the fine mapping of genes located on quantitative trait loci (QTLs) enriched chromosomes that were associated with flooding tolerance. Since different genetic backgrounds might demonstrate varying genetic mechanisms, a pan-genome of wild and cultivated soybeans was constructed to capture the entire genomic diversity, which helped to link genetic variations for genes responsible for agronomic traits [139]. Recently, the SUB1, a QTL for the submergence tolerance for rice, was demonstrated to play a role in the combination of submergence and long-term water stagnation [140]. Therefore, access to pan-genome, QTLs, and omic datasets is essential to facilitate the identification of flood-tolerant mechanisms in soybean.

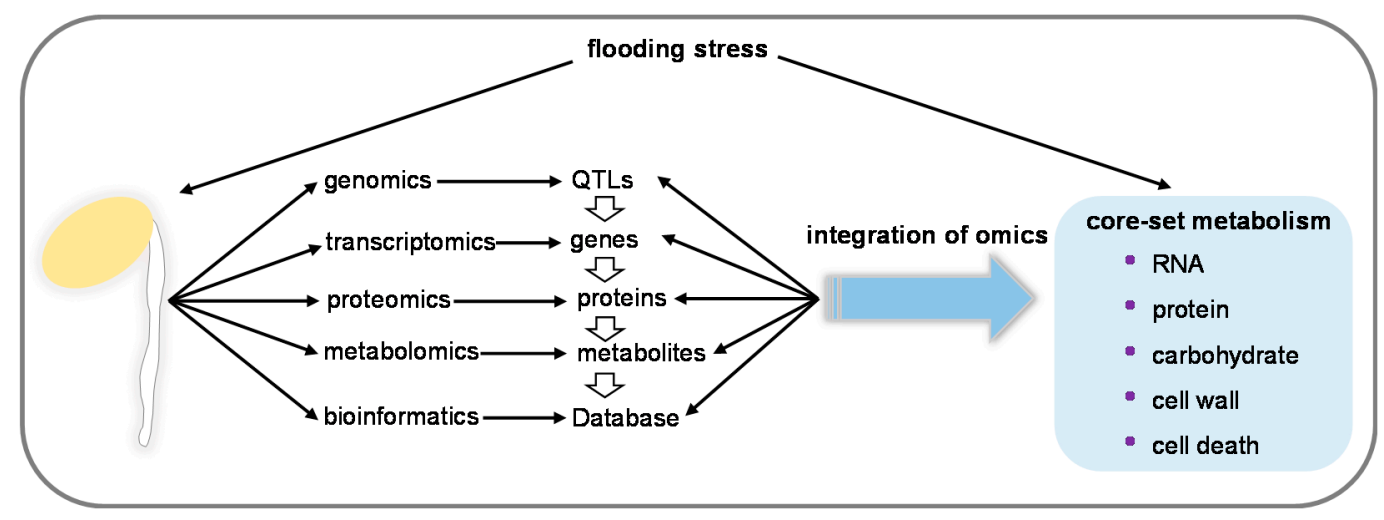

Figure 2. Overview of plant omics findings in response to flooding in soybean. Quantitative trait loci (QTLs), genes, proteins, and metabolites that are related to flooding stress were identified through genomics, transcriptomics, proteomics, and metabolomics, respectively. Soybean Proteome Database was constructed by bioinformatic analysis of omics data. Integration of soybean omics highlighted core set of flooding metabolisms in soybean. 


\section{Interaction of Molecular Mapping and Plant Omics to Flooding Tolerance in Soybean}

QTLs associated with agronomic traits represent a reservoir of alleles for breeders to create improved varieties [141]. Flooding tolerance is a complex trait, which is controlled with multiple genes and affected by interactions within genotype and stress conditions. Acquired QTLs and plant omics associated with flooding tolerance in soybean are presented in Figure 3.

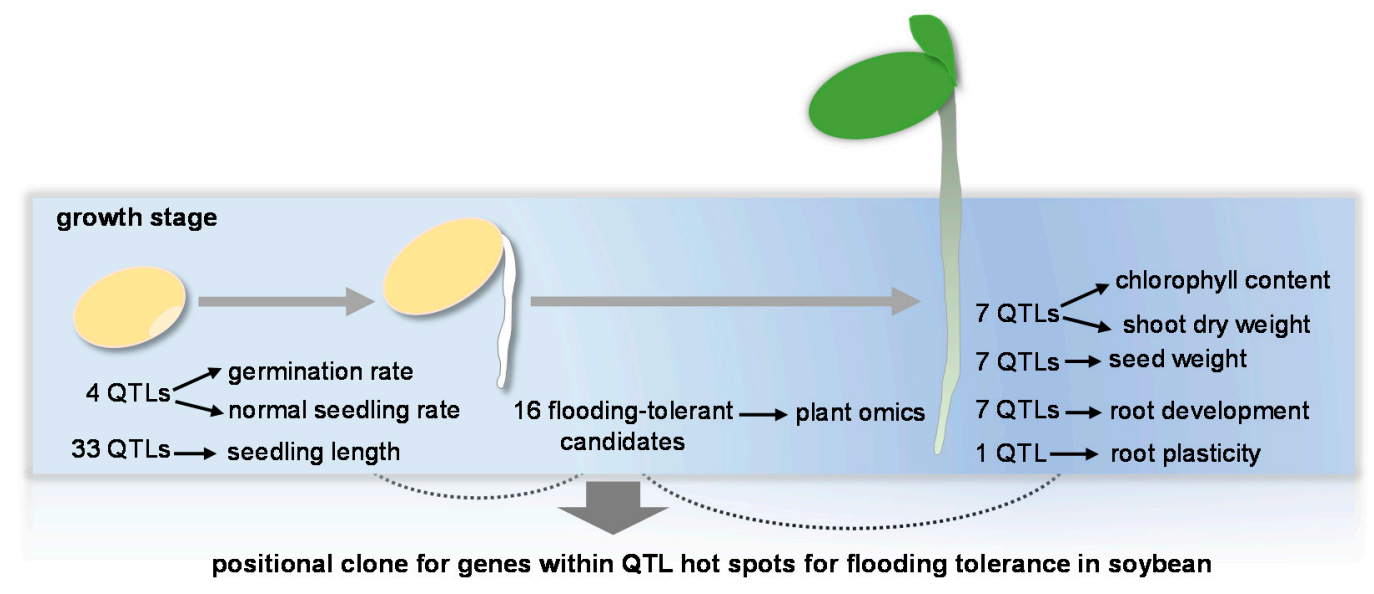

Figure 3. Interaction from QTL analysis and plant omics for flooding tolerance in soybean. QTLs associated with flooding tolerance in seed and at early vegetative growth stages are presented. Flood-tolerant indicators employed in phenotypic evaluation for QTL analysis are indicated. Flood-tolerant candidates were collected from transcriptomic and proteomic studies of soybean, including alcohol dehydrogenase 2, ATPase family AAA domain-containing protein 1, calnexin, calreticulin, chaperone 20, cytochrome P450 77A1-like, enolase, expansin-like proteins, eukaryotic aspartyl protease, glucose-6-phosphate isomerase 1, glyceraldehyde 3-phosphate dehydrogenase, glycine-rich RNA-binding protein 3, hexokinase, matrix metalloproteinase, nascent polypeptide-associated complex, and phosphofructokinase. Blue background indicates flooding stress.

In soybean, dozens of QTLs associated with flooding tolerance were identified. For seed-flooding tolerance, four QTLs were detected based on examination of germination rate and normal seedling rate [142], and 33 QTLs were identified using relative seedling length as a flooding tolerance indicator [143]. At the early vegetative growth stage, seven [13] and 20 QTLs [144] associated with flooding tolerance were obtained through phenotypic analyses of chlorophyll content, dry weight of shoot, and seed weight. Notably, seven QTLs were mapped for hypoxia-tolerant index of root development traits [145]. Furthermore, a tolerant allele of $q W T \_G m 03$ promoted soybean growth under waterlogging stress through regulation of root architecture and plasticity [146]. Chromosome region analysis showed that these QTLs for flooding tolerance were mainly located on chromosomes 4, $9,10,12,13$, and 14 [144-146]. In addition, proteomic studies indicated that chromosomes 5, 10, 11, and 13 contained abundant flooding response genes [20,23]; however, chromosome 17 contained more tolerant genes [23]. As a consequence of plant omic studies in soybean, 16 candidates associated with flooding tolerance were collected from transcriptomics and proteomics [23,38,51,53,93,127]. Although QTL hotspots assist in fine mapping and positional clone for genes responsible for flooding tolerance, normally, several candidates are involved in a specific region of the chromosome. Plant omics provides a large dataset of genes and proteins with precise locations on the chromosome based on a well-annotated genome derived from high-throughput sequencing. Taken together, a complementary strategy of QTL mapping and plant omics assists in efficient screening for flood-tolerant genes in soybean.

\section{Conclusions}

Proteomics with subcellular and PTMs is a reasonable tool for the elucidation of flood response mechanisms in soybean. Under flooding, proteins related to signaling, stress, and the antioxidative 
system are increased in the plasma membrane; ROS scavenging enzymes are suppressed in the cell wall; protein translation is suppressed through inhibition of preribosome biogenesis- and mRNA processing-related proteins in the nucleus; proteins involved in the electron-transport chain are reduced in the mitochondrion; and protein-folding related proteins decrease in the endoplasmic reticulum. The importance of PTMs reveals the core flooding responses of hormone signaling, energy metabolism, protein folding, and degradation. Furthermore, stress tolerance might be indicated to proceed with this mechanism reversely. The development of flood-tolerant soybeans using mutants and varieties as well as transgenic lines is important to interpret flood-tolerant mechanisms. Understanding plant response/tolerance mechanisms will aid in formulating strategies aimed at improving stress tolerance in crops. Especially, access to QTLs and omic datasets is essential to facilitate the identification of flood-tolerant mechanisms in crops. The information in this review has led to the development of biotechnological tools for developing crops with altered flood tolerance, as well as the identification of marker proteins/genes for stress-tolerant crops. These proteomic technologies connected with agriculture might become a good example in the field of plant science.

Supplementary Materials: Supplementary materials can be found at http://www.mdpi.com/1422-0067/21/20/ 7497/s1.

Author Contributions: Conceptualization, S.K.; writing-original draft preparation, X.W. and S.K.; writing - review and editing, X.W. and S.K. All authors have read and agreed to the published version of the manuscript.

Funding: This research received no external funding.

Conflicts of Interest: The authors declare no conflict of interest.

\section{Abbreviations}

$\begin{array}{ll}\text { ABA } & \text { Abscisic acid } \\ \text { GABA } & \text { Gamma-aminobutyric acid } \\ \text { NPs } & \text { Nanoparticles } \\ \text { PTMs } & \text { Post-translational modifications } \\ \text { QTL } & \text { Quantitative trait loci } \\ \text { ROS } & \text { Reactive oxygen species } \\ \text { TCA } & \text { Tricarboxylic acid }\end{array}$

\section{References}

1. Hashiguchi, A.; Ahsan, N.; Komatsu, S. Proteomics application of crops in the context of climatic changes. Food Res. Int. 2010, 43, 1803-1813. [CrossRef]

2. Easterling, W.E.; Aggarwal, P.K.; Batima, P.; Brander, K.M.; Erda, L.; Howden, S.M.; Kirilenko, A.; Morton, J.; Soussana, J.F.; Schmidhuber, J.; et al. (Eds.) Climate Change 2007: Impacts, Adaptation and Vulnerability. Contribution of Working Group II to the Fourth Assessment Report of the Intergovernmental Panel on Climate Change; Cambridge University Press: Cambridge, UK, 2007; pp. 273-313.

3. Rockstrom, J.; Falkenmark, M. Semiarid crop production from a hydrological perspective: Gap between potential and actual yields. Crit. Rev. Plant Sci. 2000, 19, 319-346. [CrossRef]

4. Komatsu, S.; Hiraga, S.; Yanagawa, Y. Proteomics techniques for the development of flood tolerant crops. J. Proteome Res. 2012, 11, 68-78. [CrossRef] [PubMed]

5. Arshad, M.; Frankenberger, E.T.J. Production and stability of ethylene in soil. Biol. Fert. Soils 1990, 10, 29-34. [CrossRef]

6. Bailey-Serres, J.; Fukao, T.; Ronald, P.; Ismail, A.; Heuer, S.; Mackill, D. Submergence tolerant rice: SUB1's journey from landrace to modern cultivar. Rice 2010, 3, 138-147. [CrossRef]

7. Hattori, Y.; Nagai, K.; Furukawa, S.; Song, X.J.; Kawano, R.; Sakakibara, H.; Wu, J.; Matsumoto, T.; Yoshimura, A.; Kitano, H.; et al. The ethylene response factors SNORKEL1 and SNORKEL2 allow rice to adapt to deep water. Nature 2009, 460, 1026-1030. [CrossRef] [PubMed]

8. Nagai, K.; Hattori, Y.; Ashikari, M. Stunt or elongate? Two opposite strategies by which rice adapts to floods. J. Plant Res. 2010, 123, 303-309. [CrossRef] [PubMed] 
9. Xu, K.; Xu, X.; Fukao, T.; Canlas, P.; Maghirang-Rodriguez, R.; Heuer, S.; Ismail, A.M.; Bailey-Serres, J.; Ronald, P.C.; Mackill, D.J. Sub1A is an ethylene-response-factor-like gene that confers submergence tolerance to rice. Nature 2006, 442, 705-708. [CrossRef] [PubMed]

10. Fukao, T.; Xu, K.; Ronald, P.C.; Bailey-Serres, J. A variable cluster of ethylene response factor-like genes regulates metabolic and developmental acclimation responses to submergence in rice. Plant Cell 2006, 18, 2021-2034. [CrossRef] [PubMed]

11. Niroula, R.K.; Pucciariello, C.; Ho, V.T.; Novi, G.; Fukao, T.; Perata, P. SUB1A-dependent and -independent mechanisms are involved in the flooding tolerance of wild rice species. Plant J. 2012, 72, 282-293. [CrossRef]

12. Patil, G.; Mian, R.; Vuong, T.; Pantalone, V.; Song, Q.; Chen, P.; Shannon, G.J.; Carter, T.C.; Nguyen, H.T. Molecular mapping and genomics of soybean seed protein: A review and perspective for the future. Theor. Appl. Genet. 2017, 130, 1975-1991. [CrossRef] [PubMed]

13. Githiri, S.M.; Watanabe, S.; Harada, K.; Takahashi, R. QTL analysis of flooding tolerance in soybean at an early vegetative growth stage. Plant Breed. 2006, 125, 613-618. [CrossRef]

14. Oosterhuis, D.M.; Scott, H.D.; Hampton, R.E.; Wullschleter, S.D. Physiological response of two soybean (Glycine max L. Merr) cultivars to short-term flooding. Environ. Exp. Bot. 1990, 30, 85-92. [CrossRef]

15. Shimamura, S.; Mochizuki, T.; Nada, Y.; Fukuyama, M. Formation and function of secondary aerenchyma in hypocotyl, roots and nodules of soybean (Glycine max) under flooded conditions. Plant Soil 2003, 251, 351-359. [CrossRef]

16. Yanagawa, Y.; Komatsu, S. Ubiquitin/proteasome-mediated proteolysis is involved in the response to flooding stress in soybean roots, independent of oxygen limitation. Plant Sci. 2012, 185, 250-258. [CrossRef]

17. Nanjo, Y.; Nakamura, T.; Komatsu, S. Identification of indicator proteins associated with flooding injury in soybean seedlings using label-free quantitative proteomics. J. Proteome Res. 2013, 12, 4785-4798. [CrossRef]

18. Komatsu, S.; Shirasaka, N.; Sakata, K. 'Omics' techniques for identifying flooding-response mechanisms in soybean. J. Proteom. 2013, 93, 169-178. [CrossRef]

19. Komatsu, S.; Sakata, K.; Nanjo, Y. 'Omics' techniques and their use to identify how soybean responds to flooding. J. Anal. Sci. Technol. 2015, 6, 9. [CrossRef]

20. Wang, X.; Komatsu, S. Proteomic approaches to uncover the flooding and drought stress response mechanisms in soybean. J. Proteom. 2018, 172, 201-215. [CrossRef]

21. Hossain, Z.; Komatsu, S. Potentiality of soybean proteomics in untying the mechanism of flood and drought stress tolerance. Proteomes 2014, 2, 107-127. [CrossRef]

22. Komatsu, S.; Tougou, M.; Nanjo, Y. Proteomic techniques and management of flooding tolerance in soybean. J. Proteome Res. 2015, 14, 3768-3778. [CrossRef] [PubMed]

23. Yin, X.; Komatsu, S. Comprehensive analysis of response and tolerant mechanisms in early-stage soybean at initial-flooding stress. J. Proteom. 2017, 169, 225-232. [CrossRef] [PubMed]

24. Bacanamwo, M.; Purcell, L.C. Soybean root morphological and anatomical traits associated with acclimation to flooding. Crop Sci. 1999, 39, 143-149. [CrossRef]

25. VanToai, T.T.; St. Martin, S.K.; Chase, K.; Boru, G.; Schnipke, V.; Schmitthenner, A.F.; Lark, K.G. Identification of a QTL associated with tolerance of soybean to soil waterlogging. Crop Sci. 2001, 41, 1247-1252. [CrossRef]

26. Shi, F.; Yamamoto, R.; Shimamura, S.; Hiraga, S.; Nakayama, N.; Nakamura, T.; Yukawa, K.; Hachinohe, M.; Matsumoto, H.; Komatsu, S. Cytosolic ascorbate peroxidase 2 (cAPX 2) is involved in the soybean response to flooding. Phytochemistry 2008, 69, 1295-1303. [CrossRef]

27. Hashiguchi, A.; Sakata, K.; Komatsu, S. Proteome analysis of early-stage soybean seedlings under flooding stress. J. Proteome Res. 2009, 8, 2058-2069. [CrossRef]

28. Khatoon, A.; Rehman, S.; Oh, M.W.; Woo, S.H.; Komatsu, S. Analysis of response mechanism in soybean under low oxygen and flooding stresses using gel-base proteomics technique. Mol. Biol. Rep. 2012, 39, 10581-10594. [CrossRef]

29. Khatoon, A.; Rehman, S.; Hiraga, S.; Makino, T.; Komatsu, S. Organ-specific proteomics analysis for identification of response mechanism in soybean seedlings under flooding stress. J. Proteom. 2012, 75, 5706-5723. [CrossRef]

30. Salavati, A.; Khatoon, A.; Nanjo, Y.; Komatsu, S. Analysis of proteomic changes in roots of soybean seedlings during recovery after flooding. J. Proteom. 2012, 75, 878-893. [CrossRef]

31. Nanjo, Y.; Jang, H.Y.; Kim, H.S.; Hiraga, S.; Woo, S.H.; Komatsu, S. Analyses of flooding tolerance of soybean varieties at emergence and varietal differences in their proteomes. Phytochemistry 2014, 106, 25-36. [CrossRef] 
32. Sakazono, S.; Nagata, T.; Matsuo, R.; Kajihara, S.; Watanabe, M.; Ishimoto, M.; Shimamura, S.; Harada, K.; Takahashi, R.; Mochizuki, T. Variation in root development response to flooding among 92 soybean lines during early growth stages. Plant Prod. Sci. 2014, 17, 228-236. [CrossRef]

33. Yin, X.; Sakata, K.; Komatsu, S. Phosphoproteomics reveals the effect of ethylene in soybean root under flooding stress. J. Proteome Res. 2014, 13, 5618-5634. [CrossRef] [PubMed]

34. Jin-Woong, C.H.O.; Yamakawa, T. Effects on growth and seed yield of small seed soybean cultivars of flooding conditions in paddy field. J. Fac. Agric. Kyushu Univ. 2006, 51, 189-193.

35. Shimamura, S.; Mochizuki, T.; Nada, Y.; Fukuyama, M. Secondary aerenchyma formation and its relation to nitrogen fixation in root nodules of soybean plants (Glycine max) grown under flooded conditions. Plant Prod. Sci. 2002, 5, 294-300. [CrossRef]

36. Thomas, A.L.; Guerreiro, S.M.; Sodek, L. Aerenchyma formation and recovery from hypoxia of the flooded root system of nodulated soybean. Ann. Bot. 2005, 96, 1191-1198. [CrossRef] [PubMed]

37. Komatsu, S.; Kobayashi, Y.; Nishizawa, K.; Nanjo, Y.; Furukawa, K. Comparative proteomics analysis of differentially expressed proteins in soybean cell wall during flooding stress. Amino Acids 2010, 39, 1435-1449. [CrossRef] [PubMed]

38. Yin, X.; Nishimura, M.; Hajika, M.; Komatsu, S. Quantitative proteomics reveals the flooding-tolerance mechanism in mutant and abscisic acid-treated soybean. J. Proteome Res. 2016, 15, 2008-2025. [CrossRef]

39. Komatsu, S.; Wada, T.; Abaléa, Y.; Nouri, M.Z.; Nanjo, Y.; Nakayama, N.; Shimamura, S.; Yamamoto, R.; Nakamura, T.; Furukawa, K. Analysis of plasma membrane proteome in soybean and application to flooding stress response. J. Proteome Res. 2009, 8, 4487-4499. [CrossRef]

40. Komatsu, S.; Makino, T.; Yasue, H. Proteomic and biochemical analyses of the cotyledon and root of flooding-stressed soybean plants. PLoS ONE 2013, 8, e65301. [CrossRef]

41. Yin, X.; Sakata, K.; Nanjo, Y.; Komatsu, S. Analysis of initial changes in the proteins of soybean root tip under flooding stress using gel-free and gel-based proteomic techniques. J. Proteom. 2014, 106, 1-16. [CrossRef]

42. Wang, X.; Komatsu, S. Gel-free/label-free proteomic analysis of endoplasmic reticulum proteins in soybean root tips under flooding and drought stresses. J. Proteome Res. 2016, 15, 2211-2227. [CrossRef]

43. Wang, X.; Komatsu, S. Proteomic analysis of calcium effects on soybean root tip under flooding and drought stresses. Plant Cell Physiol. 2017, 58, 1405-1420. [CrossRef] [PubMed]

44. Komatsu, S.; Nanjo, Y.; Nishimura, M. Proteomic analysis of the flooding tolerance mechanism in mutant soybean. J. Proteom. 2013, 79, 231-250. [CrossRef] [PubMed]

45. Hashimoto, T.; Mustafa, G.; Nishiuchi, T.; Komatsu, S. Comparative analysis of the effect of inorganic and organic chemicals with silver nanoparticles on soybean under flooding stress. Int. J. Mol. Sci. 2020, 21, 1300. [CrossRef] [PubMed]

46. Komatsu, S.; Kuji, R.; Nanjo, Y.; Hiraga, S.; Furukawa, K. Comprehensive analysis of endoplasmic reticulum-enriched fraction in root tips of soybean under flooding stress using proteomics techniques. J. Proteom. 2012, 77, 531-560. [CrossRef] [PubMed]

47. Mustafa, G.; Komatsu, S. Quantitative proteomics reveals the effect of protein glycosylation in soybean root under flooding stress. Front. Plant Sci. 2014, 5, 627. [CrossRef]

48. Yin, X.; Komatsu, S. Nuclear proteomics reveals the role of protein synthesis and chromatin structure in root tip of soybean during the initial stage of flooding stress. J. Proteome Res. 2016, 15, 2283-2298. [CrossRef]

49. Wang, X.; Oh, M.; Sakata, K.; Komatsu, S. Gel-free/label-free proteomic analysis of root tip of soybean over time under flooding and drought stresses. J. Proteom. 2016, 130, 42-55. [CrossRef]

50. Nanjo, Y.; Skultety, L.; Ashraf, Y.; Komatsu, S. Comparative proteomic analysis of early-stage soybean seedlings responses to flooding by using gel and gel-free techniques. J. Proteome Res. 2010, 9, 3989-4002. [CrossRef]

51. Wang, X.; Zhu, W.; Hashiguchi, A.; Nishimura, M.; Tian, J.; Komatsu, S. Metabolic profiles of flooding-tolerant mechanism in early-stage soybean responding to initial stress. Plant Mol. Biol. 2017, 94, 669-685. [CrossRef]

52. Nakamura, T.; Yamamoto, R.; Hiraga, S.; Nakayama, N.; Okazaki, K.; Takahashi, H.; Uchimiya, H.; Komatsu, S. Evaluation of metabolite alteration under flooding stress in soybeans. JARQ Jpn. Agric. Res. Q. 2012, 46, 237-248. [CrossRef]

53. Wang, X.; Sakata, K.; Komatsu, S. An integrated approach of proteomics and computational genetic modification effectiveness analysis to uncover the mechanisms of flood tolerance in soybeans. Int. J. Mol. Sci. 2018, 19, 1301. [CrossRef] [PubMed] 
54. Komatsu, S.; Han, C.; Nanjo, Y.; Altaf-Un-Nahar, M.; Wang, K.; He, D.; Yang, P. Label-free quantitative proteomic analysis of abscisic acid effect in early-stage soybean under flooding. J. Proteome Res. 2013, 12, 4769-4784. [CrossRef] [PubMed]

55. Yin, X.; Komatsu, S. Quantitative proteomics of nuclear phosphoproteins in the root tip of soybean during the initial stages of flooding stress. J. Proteom. 2015, 119, 183-195. [CrossRef] [PubMed]

56. Wang, X.; Oh, M.; Komatsu, S. Characterization of S-adenosylmethionine synthetases in soybean under flooding and drought stresses. Biol. Plant. 2016, 60, 269-278. [CrossRef]

57. Gemperline, E.; Keller, C.; Li, L. Mass spectrometry in plant-omics. Anal. Chem. 2016, 88, 3422-3434. [CrossRef]

58. Alvarez, S.; Naldrett, M.J. Plant structure and specificity-challenges and sample preparation considerations for proteomics. Adv. Exp. Med. Biol. 2016, 919, 63-81.

59. Alam, I.; Lee, D.G.; Kim, K.H.; Park, C.H.; Sharmin, S.A.; Lee, H.; Oh, K.W.; Yun, B.W.; Lee, B.H. Proteome analysis of soybean roots under waterlogging stress at an early vegetative stage. J. Biosci. 2010, 35, 49-62. [CrossRef]

60. Oskuei, B.K.; Yin, X.; Hashiguchi, A.; Bandehagh, A.; Komatsu, S. Proteomic analysis of soybean seedling leaf under waterlogging stress in a time-dependent manner. Biochim. Biophys. Acta Proteins Proteom. 2017, 1865, 1167-1177. [CrossRef]

61. Khan, M.N.; Sakata, K.; Hiraga, S.; Komatsu, S. Quantitative proteomics reveals that peroxidases play key roles in post-flooding recovery in soybean roots. J. Proteome Res. 2014, 13, 5812-5828. [CrossRef]

62. Khan, M.N.; Sakata, K.; Komatsu, S. Proteomic analysis of soybean hypocotyl during recovery after flooding stress. J. Proteom. 2015, 121, 15-27. [CrossRef] [PubMed]

63. Komatsu, S.; Hiraga, S.; Nouri, M.Z. Analysis of flooding-responsive proteins localized in the nucleus of soybean root tips. Mol. Biol. Rep. 2014, 41, 1127-1139. [CrossRef] [PubMed]

64. Oh, M.; Nanjo, Y.; Komatsu, S. Identification of nuclear proteins in soybean under flooding stress using proteomic technique. Protein Pept. Lett. 2014, 21, 458-467. [CrossRef] [PubMed]

65. Komatsu, S.; Yamamoto, A.; Nakamura, T.; Nouri, M.Z.; Nanjo, Y.; Nishizawa, K.; Furukawa, K. Comprehensive analysis of mitochondria in roots and hypocotyls of soybean under flooding stress using proteomics and metabolomics techniques. J. Proteome Res. 2011, 10, 3993-4004. [CrossRef]

66. Kamal, A.H.; Komatsu, S. Involvement of reactive oxygen species and mitochondrial proteins in biophoton emission in roots of soybean plants under flooding stress. J. Proteome Res. 2015, 14, 2219-2236. [CrossRef] [PubMed]

67. Hashiguchi, A.; Komatsu, S. Impact of post-translational modifications of crop proteins under abiotic stress. Proteomes 2016, 4, 42. [CrossRef]

68. Nanjo, Y.; Skultety, L.; Uváčková, L.; Klubicová, K.; Hajduch, M.; Komatsu, S. Mass spectrometry-based analysis of proteomic changes in the root tips of flooded soybean seedlings. J. Proteome Res. 2012, 11, 372-385. [CrossRef]

69. Hashiguchi, A.; Komatsu, S. Early changes in S-nitrosoproteome in soybean seedling under flooding stress. Plant Mol. Biol. Rep. 2018, 36, 822-831. [CrossRef]

70. Nanjo, Y.; Maruyama, K.; Yasue, H.; Yamaguchi-Shinozaki, K.; Shinozaki, K.; Komatsu, S. Transcriptional responses to flooding stress in roots including hypocotyl of soybean seedlings. Plant Mol. Biol. 2011, 77, 129-144. [CrossRef]

71. Chen, W.; Yao, Q.; Patil, G.B.; Agarwal, G.; Deshmukh, R.K.; Lin, L.; Wang, B.; Wang, Y.; Prince, S.J.; Song, L.; et al. Identification and comparative analysis of differential gene expression in soybean leaf tissue under drought and flooding stress revealed by RNA-Seq. Front. Plant Sci. 2016, 7, 1044. [CrossRef]

72. Tamang, B.G.; Magliozzi, J.O.; Maroof, M.A.; Fukao, T. Physiological and transcriptomic characterization of submergence and reoxygenation responses in soybean seedlings. Plant Cell Environ. 2014, 37, 2350-2365. [CrossRef] [PubMed]

73. Sakata, K.; Ohyanagi, H.; Nobori, H.; Nakamura, T.; Hashiguchi, A.; Nanjo, Y.; Mikami, Y.; Yunokawa, H.; Komatsu, S. Soybean proteome database: A data resource for plant differential omics. J. Proteome Res. 2009, 8, 3539-3548. [CrossRef] [PubMed]

74. Ohyanagi, H.; Sakata, K.; Komatsu, S. Soybean Proteome Database 2012: Update on the comprehensive data repository for soybean proteomics. Front. Plant Sci. 2012, 3, 110. [CrossRef] [PubMed] 
75. Komatsu, S.; Wang, X.; Yin, X.; Nanjo, Y.; Ohyanagi, H.; Sakata, K. Integration of gel-based and gel-free proteomic data for functional analysis of proteins through Soybean Proteome Database. J. Proteom. 2017, 163, 52-66. [CrossRef] [PubMed]

76. Sadiq, I.; Fanucchi, F.; Paparelli, E.; Alpi, E.; Bachi, A.; Alpi, A.; Perata, P. Proteomic identification of differentially expressed proteins in the anoxic rice coleoptile. J. Plant Physiol. 2011, 168, 2234-2243. [CrossRef]

77. Xiong, Q.; Cao, C.; Shen, T.; Zhong, L.; He, H.; Chen, X. Comprehensive metabolomic and proteomic analysis in biochemical metabolic pathways of rice spikes under drought and submergence stress. Biochim. Biophys. Acta Proteins Proteom. 2019, 1867, 237-247. [CrossRef]

78. Xiong, Q.; Shen, T.; Zhong, L.; Zhu, C.; Peng, X.; He, X.; Fu, J.; Ouyang, L.; Bian, J.; Hu, L.; et al. Comprehensive metabolomic, proteomic and physiological analyses of grain yield reduction in rice under abrupt drought-flood alternation stress. Physiol. Plant. 2019, 167, 564-584. [CrossRef] [PubMed]

79. Chen, Y.; Chen, X.; Wang, H.; Bao, Y.; Zhang, W. Examination of the leaf proteome during flooding stress and the induction of programmed cell death in maize. Proteome Sci. 2014, 12, 33. [CrossRef]

80. Yu, F.; Han, X.; Geng, C.; Zhao, Y.; Zhang, Z.; Qiu, F. Comparative proteomic analysis revealing the complex network associated with waterlogging stress in maize (Zea mays L.) seedling root cells. Proteomics 2015, 15, 135-147. [CrossRef]

81. Meisrimler, C.N.; Buck, F.; Lüthje, S. Alterations in soluble Class III peroxidases of maize shoots by flooding stress. Proteomes 2014, 2, 303-322. [CrossRef]

82. Hu, J.; Ren, B.; Dong, S.; Liu, P.; Zhao, B.; Zhang, J. Comparative proteomic analysis reveals that exogenous 6-benzyladenine (6-BA) improves the defense system activity of waterlogged summer maize. BMC Plant Biol. 2020, 20, 44. [CrossRef] [PubMed]

83. Kong, F.J.; Oyanagi, A.; Komatsu, S. Cell wall proteome of wheat roots under flooding stress using gel-based and LC MS/MS-based proteomics approaches. Biochim. Biophys. Acta 2010, 1804, 124-136. [CrossRef] [PubMed]

84. Wang, X.; Huang, M.; Zhou, Q.; Cai, J.; Dai, T.; Cao, W.; Jiang, D. Physiological and proteomic mechanisms of waterlogging priming improves tolerance to waterlogging stress in wheat (Triticum aestivum L.). Environ. Exp. Bot. 2016, 132, 175-182. [CrossRef]

85. Pan, R.; He, D.; Xu, L.; Zhou, M.; Li, C.; Wu, C.; Xu, Y.; Zhang, W. Proteomic analysis reveals response of differential wheat (Triticum aestivum L.) genotypes to oxygen deficiency stress. BMC Genom. 2019, $20,60$. [CrossRef] [PubMed]

86. Yan, M.; Xue, C.; Xiong, Y.; Meng, X.; Li, B.; Shen, R.; Lan, P. Proteomic dissection of the similar and different responses of wheat to drought, salinity and submergence during seed germination. J. Proteom. 2020, 220, 103756. [CrossRef] [PubMed]

87. Xu, J.; Qiao, X.; Tian, Z.; Zhang, X.; Zou, X.; Cheng, Y.; Lu, G.; Zeng, L.; Fu, G.; Ding, X.; et al. Proteomic analysis of rapeseed root response to waterlogging stress. Plants 2018, 7, 71. [CrossRef]

88. Luan, H.; Shen, H.; Pan, Y.; Guo, B.; Lv, C.; Xu, R. Elucidating the hypoxic stress response in barley (Hordeum vulgare L.) during waterlogging: A proteomics approach. Sci. Rep. 2018, 8, 9655. [CrossRef]

89. Zeng, N.; Yang, Z.; Zhang, Z.; Hu, L.; Chen, L. Comparative transcriptome combined with proteome analyses revealed key factors involved in alfalfa (Medicago sativa) response to waterlogging stress. Int. J. Mol. Sci. 2019, 20, 1359. [CrossRef]

90. Bailly, C. The signalling role of ROS in the regulation of seed germination and dormancy. Biochem. J. 2019, 476, 3019-3032. [CrossRef]

91. Fukao, T.; Bailey-Serres, J. Plant responses to hypoxia-is survival a balancing act? Trends Plant Sci. 2004, 9, 449-456. [CrossRef]

92. Liu, S.; Zhang, M.; Feng, F.; Tian, Z. Toward a 'Green Revolution' for soybean. Mol. Plant 2020, 13, 688-697. [CrossRef] [PubMed]

93. Tougou, M.; Hashiguchi, A.; Yukawa, K.; Nanjo, Y.; Hiraga, S.; Nakamura, T.; Nishizawa, K.; Komatsu, S. Responses to flooding stress in soybean seedlings with the alcohol dehydrogenase transgene. Plant Biotechnol. 2012, 29, 301-305. [CrossRef]

94. Zhong, Z.; Furuya, T.; Ueno, K.; Yamaguchi, H.; Hitachi, K.; Tsuchida, K.; Tani, M.; Tian, J.; Komatsu, S. Proteomic analysis of irradiation with millimeter waves on soybean growth under flooding conditions. Int. J. Mol. Sci. 2020, 21, 486. [CrossRef] [PubMed] 
95. Li, X.; Rehman, S.U.; Yamaguchi, H.; Hitachi, K.; Tsuchida, K.; Yamaguchi, T.; Sunohara, Y.; Matsumoto, H.; Komatsu, S. Proteomic analysis of the effect of plant-derived smoke on soybean during recovery from flooding stress. J. Proteom. 2018, 181, 238-248. [CrossRef] [PubMed]

96. Zhong, Z.; Kobayashi, T.; Zhu, W.; Imai, H.; Zhao, R.; Ohno, T.; Rehman, S.U.; Uemura, M.; Tian, J.; Komatsu, S. Plant-derived smoke enhances plant growth through ornithine-synthesis pathway and ubiquitin-proteasome pathway in soybean. J. Proteom. 2020, 221, 103781. [CrossRef]

97. Otori, M.; Murashita, Y.; Rehman, S.U.; Komatsu, S. Proteomic study to understand promotive effects of plant-derived smoke on soybean (Glycine max L.) root growth under flooding stress. Plant Mol. Biol. Rep. 2020, 1-10. [CrossRef]

98. Hossain, Z.; Mustafa, G.; Sakata, K.; Komatsu, S. Insights into the proteomic response of soybean towards $\mathrm{Al}_{2} \mathrm{O}_{3}, \mathrm{ZnO}$, and $\mathrm{Ag}$ nanoparticles stress. J. Hazard Mater. 2016, 304, 291-305. [CrossRef]

99. Mustafa, G.; Komatsu, S. Insights into the response of soybean mitochondrial proteins to various sizes of aluminum oxide nanoparticles under flooding stress. J. Proteome Res. 2016, 15, 4464-4475. [CrossRef]

100. Mustafa, G.; Sakata, K.; Komatsu, S. Proteomic analysis of flooded soybean root exposed to aluminum oxide nanoparticles. J. Proteom. 2015, 128, 280-297. [CrossRef]

101. Yasmeen, F.; Raja, N.I.; Mustafa, G.; Sakata, K.; Komatsu, S. Quantitative proteomic analysis of post-flooding recovery in soybean root exposed to aluminum oxide nanoparticles. J. Proteom. 2016, 143, 136-150. [CrossRef]

102. Mustafa, G.; Sakata, K.; Hossain, Z.; Komatsu, S. Proteomic study on the effects of silver nanoparticles on soybean under flooding stress. J. Proteom. 2015, 122, 100-118. [CrossRef] [PubMed]

103. Mustafa, G.; Sakata, K.; Komatsu, S. Proteomic analysis of soybean root exposed to varying sizes of silver nanoparticles under flooding stress. J. Proteom. 2016, 148, 113-125. [CrossRef] [PubMed]

104. Mustafa, G.; Hasan, M.; Yamaguchi, H.; Hitachi, K.; Tsuchida, K.; Komatsu, S. A comparative proteomic analysis of engineered and bio synthesized silver nanoparticles on soybean seedlings. J. Proteom. 2020, 224, 103833. [CrossRef]

105. Lin, Y.; Li, W.; Zhang, Y.; Xia, C.; Liu, Y.; Wang, C.; Xu, R.; Zhang, L. Identification of genes/proteins related to submergence tolerance by transcriptome and proteome analyses in soybean. Sci. Rep. 2019, 9, 14688. [CrossRef]

106. Zaman, M.S.U.; Malik, A.I.; Erskine, W.; Kaur, P. Changes in gene expression during germination reveal pea genotypes with either 'quiescence' or 'escape' mechanisms of waterlogging tolerance. Plant Cell Environ. 2019, 42, 245-258. [CrossRef] [PubMed]

107. Bailey-Serres, J.; Voesenek, L.A. Flooding stress: Acclimations and genetic diversity. Annu. Rev. Plant Biol. 2008, 59, 313-339. [CrossRef]

108. Ismond, K.P.; Dolferus, R.; de Pauw, M.; Dennis, E.S.; Good, A.G. Enhanced low oxygen survival in Arabidopsis through increased metabolic flux in the fermentative pathway. Plant Physiol. 2003, 132, 1292-1302. [CrossRef]

109. Meng, X.; Li, L.; Narsai, R.; De Clercq, I.; Whelan, J.; Berkowitz, O. Mitochondrial signalling is critical for acclimation and adaptation to flooding in Arabidopsis thaliana. Plant J. 2020, 103, 227-247. [CrossRef]

110. Kurokawa, Y.; Nagai, K.; Huan, P.D.; Shimazaki, K.; Qu, H.; Mori, Y.; Toda, Y.; Kuroha, T.; Hayashi, N.; Aiga, S.; et al. Rice leaf hydrophobicity and gas films are conferred by a wax synthesis gene (LGF1) and contribute to flood tolerance. New Phytol. 2018, 218, 1558-1569. [CrossRef]

111. Yu, F.; Liang, K.; Fang, T.; Zhao, H.; Han, X.; Cai, M.; Qiu, F. A group VII ethylene response factor gene, ZmEREB180, coordinates waterlogging tolerance in maize seedlings. Plant Biotechnol. J. 2019, 17, 2286-2298. [CrossRef]

112. Song, L.; Valliyodan, B.; Prince, S.; Wan, J.; Nguyen, H.T. Characterization of the XTH gene family: New insight to the roles in soybean flooding tolerance. Int. J. Mol. Sci. 2018, 19, 2705. [CrossRef] [PubMed]

113. Komatsu, S.; Deschamps, T.; Hiraga, S.; Kato, M.; Chiba, M.; Hashiguchi, A.; Tougou, M.; Shimamura, S.; Yasue, $\mathrm{H}$. Characterization of a novel flooding stress-responsive alcohol dehydrogenase expressed in soybean roots. Plant Mol. Biol. 2011, 77, 309-322. [CrossRef] [PubMed]

114. Sheen, D.M.; McMakin, D.L.; Hall, T.E. Detection of explosives by millimeter-wave imaging. Count. Detect. Tech. Explos. 2007, 237-277. [CrossRef]

115. Betskii, O.; Lebedeva, N.; Tambiev, A.; Kirikova, N.; Slavin, V. Millimeter waves in the newest agricultural biotechnologies. J. Sci. Eng. 2007, 23, 236-252.

116. Sasidharan, R.; Voesenek, L.A. Ethylene-mediated acclimations to flooding stress. Plant Physiol. 2015, 169, 3-12. [CrossRef] 
117. Benschop, J.J.; Jackson, M.B.; Gühl, K.; Vreeburg, R.A.; Croker, S.J.; Peeters, A.J.; Voesenek, L.A. Contrasting interactions between ethylene and abscisic acid in Rumex species differing in submergence tolerance. Plant J. 2005, 44, 756-768. [CrossRef]

118. Hwang, S.Y.; Vantoai, T.T. Abscisic acid induces anaerobiosis tolerance in corn. Plant Physiol. 1991, 97, 593-597. [CrossRef]

119. Kim, Y.H.; Hwang, S.J.; Waqas, M.; Khan, A.L.; Lee, J.H.; Lee, J.D.; Nguyen, H.T.; Lee, I.J. Comparative analysis of endogenous hormones level in two soybean (Glycine max L.) lines differing in waterlogging tolerance. Front. Plant Sci. 2015, 6, 714. [CrossRef]

120. Soós, V.; Sebestyén, E.; Juhász, A.; Pintér, J.; Light, M.E.; Van Staden, J.; Balázs, E. Stress-related genes define essential steps in the response of maize seedlings to smoke-water. Funct. Integr. Genom. 2009, 9, 231-242. [CrossRef]

121. Ghebrehiwot, H.M.; Kulkarni, M.G.; Kirkman, K.P.; Van Staden, J. Smoke-water and a smoke-isolated butenolide improve germination and seedling vigour of Eragrostis tef (Zucc.) trotter under high temperature and low osmotic potential. J. Agron. Crop. Sci. 2008, 194, 270-277. [CrossRef]

122. Jamil, M.; Kanwal, M.; Aslam, M.M.; Khan, S.U.; Malook, I.; Tu, J.; Rehman, S.U. Effect of plant-derived smoke priming on physiological and biochemical characteristics of rice under salt stress condition. Aust. J. Crop Sci. 2014, 8, 159-170.

123. Scaffidi, A.; Waters, M.T.; Ghisalberti, E.L.; Dixon, K.W.; Flematti, G.R.; Smith, S.M. Carlactone-independent seedling morphogenesis in Arabidopsis. Plant J. 2013, 76, 1-9. [CrossRef] [PubMed]

124. Soundappan, I.; Bennett, T.; Morffy, N.; Liang, Y.; Stanga, J.P.; Abbas, A.; Leyser, O.; Nelson, D.C. SMAX1-LIKE/D53 family members enable distinct MAX2-dependent responses to strigolactones and karrikins in Arabidopsis. Plant Cell 2015, 27, 3143-3159. [CrossRef] [PubMed]

125. Nel, A.; Xia, T.; Mädler, L.; Li, N. Toxic potential of materials at the nanolevel. Science 2006, 311, $622-627$. [CrossRef]

126. Nakayama, T.J.; Rodrigues, F.A.; Neumaier, N.; Marcolino-Gomes, J.; Molinari, H.B.C.; Santiago, T.R.; Formighieri, E.F.; Basso, M.F.; Farias, J.R.B.; Emygdio, B.M.; et al. Insights into soybean transcriptome reconfiguration under hypoxic stress: Functional, regulatory, structural, and compositional characterization. PLoS ONE 2017, 12, e0187920. [CrossRef] [PubMed]

127. Yin, X.; Hiraga, S.; Hajika, M.; Nishimura, M.; Komatsu, S. Transcriptomic analysis reveals the flooding tolerant mechanism in flooding tolerant line and abscisic acid treated soybean. Plant Mol. Biol. 2017, 93, 479-496. [CrossRef]

128. Coutinho, I.D.; Henning, L.M.M.; Döpp, S.A.; Nepomuceno, A.; Moraes, L.A.C.; Marcolino-Gomes, J.; Richter, C.; Schwalbe, H.; Colnago, L.A. Flooded soybean metabolomic analysis reveals important primary and secondary metabolites involved in the hypoxia stress response and tolerance. Environ. Exp. Bot. 2018, 153, 176-187. [CrossRef]

129. Saibi, W.; Zouari, N.; Masmoudi, K.; Brini, F. Role of the durum wheat dehydrin in the function of proteases conferring salinity tolerance in Arabidopsis thaliana transgenic lines. Int. J. Biol. Macromol. 2016, 85, 311-316. [CrossRef]

130. Yao, X.; Xiong, W.; Ye, T.; Wu, Y. Overexpression of the aspartic protease ASPG1 gene confers drought avoidance in Arabidopsis. J. Exp. Bot. 2012, 63, 2579-2593. [CrossRef]

131. Wang, B.; Wang, G.; Shen, F.; Zhu, S. A glycine-rich RNA-binding protein, CsGR-RBP3, is involved in defense responses against cold stress in harvested cucumber (Cucumis sativus L.) fruit. Front. Plant Sci. 2018, 9, 540. [CrossRef]

132. Preissler, S.; Deuerling, E. Ribosome-associated chaperones as key players in proteostasis. Trends Biochem. Sci. 2012, 37, 274-283. [CrossRef] [PubMed]

133. Howell, S.H. Endoplasmic reticulum stress responses in plants. Annu. Rev. Plant Biol. 2013, 64, 477-499. [CrossRef] [PubMed]

134. Chen, L.J.; Zou, W.S.; Fei, C.Y.; Wu, G.; Li, X.Y.; Lin, H.H.; Xi, D.H. $\alpha$-Expansin EXPA4 positively regulates abiotic stress tolerance but negatively regulates pathogen resistance in Nicotiana tabacum. Plant Cell Physiol. 2018, 59, 2317-2330. [CrossRef] [PubMed]

135. Federici, L.; Di Matteo, A.; Fernandez-Recio, J.; Tsernoglou, D.; Cervone, F. Polygalacturonase inhibiting proteins: Players in plant innate immunity? Trends Plant Sci. 2006, 11, 65-70. [CrossRef] 
136. Arora, K.; Panda, K.K.; Mittal, S.; Mallikarjuna, M.G.; Rao, A.R.; Dash, P.K.; Thirunavukkarasu, N. RNAseq revealed the important gene pathways controlling adaptive mechanisms under waterlogged stress in maize. Sci. Rep. 2017, 7, 10950. [CrossRef] [PubMed]

137. Mustroph, A. Improving flooding tolerance of crop plants. Agronomy 2018, 8, 160. [CrossRef]

138. Schmutz, J.; Cannon, S.B.; Schlueter, J.; Ma, J.; Mitros, T.; Nelson, W.; Hyten, D.L.; Song, Q.; Thelen, J.J.; Cheng, J.; et al. Genome sequence of the palaeopolyploid soybean. Nature 2010, 463, 178-183. [CrossRef]

139. Liu, Y.; Du, H.; Li, P.; Shen, Y.; Peng, H.; Liu, S.; Zhou, G.A.; Zhang, H.; Liu, Z.; Shi, M.; et al. Pan-genome of wild and cultivated soybeans. Cell 2020, 182, 162-176. [CrossRef]

140. Kato, Y.; Collard, B.C.Y.; Septiningsih, E.M.; Ismail, A.M. Increasing flooding tolerance in rice: Combining tolerance of submergence and of stagnant flooding. Ann. Bot. 2020, 124, 1199-1210. [CrossRef]

141. Nguyen, K.L.; Grondin, A.; Courtois, B.; Gantet, P. Next-generation sequencing accelerates crop gene discovery. Trends. Plant Sci. 2019, 24, 263-274. [CrossRef]

142. Sayama, T.; Nakazaki, T.; Ishikawa, G.; Yagasaki, K.; Yamada, N.; Hirota, N.; Hirata, K.; Yoshikawa, T.; Saito, H.; Teraishi, M.; et al. QTL analysis of seed-flooding tolerance in soybean (Glycine max [L.] Merr.). Plant Sci. 2009, 176, 514-521. [CrossRef] [PubMed]

143. Ali, M.J.; Xing, G.; He, J.; Zhao, T.; Gai, J. Detecting the QTL-allele system controlling seed-flooding tolerance in a nested association mapping population of soybean. Crop J. 2020, 8, 781-792. [CrossRef]

144. Dhungana, S.K.; Kim, H.S.; Kang, B.K.; Seo, J.H.; Kim, H.T.; Shin, S.O.; Park, C.H.; Kwak, D.Y. Quantitative trait loci mapping for flooding tolerance at an early growth stage of soybean recombinant inbred line population. Plant Breed. 2020, 139, 626-638. [CrossRef]

145. Van Nguyen, L.; Takahashi, R.; Githiri, S.M.; Rodriguez, T.O.; Tsutsumi, N.; Kajihara, S.; Sayama, T.; Ishimoto, M.; Harada, K.; Suematsu, K.; et al. Mapping quantitative trait loci for root development under hypoxia conditions in soybean (Glycine max L. Merr.). Theor. Appl. Genet. 2017, 130, 743-755. [CrossRef] [PubMed]

146. Ye, H.; Song, L.; Chen, H.; Valliyodan, B.; Cheng, P.; Ali, L.; Vuong, T.; Wu, C.; Orlowski, J.; Buckley, B.; et al. A major natural genetic variation associated with root system architecture and plasticity improves waterlogging tolerance and yield in soybean. Plant Cell Environ. 2018, 41, 2169-2182. [CrossRef] [PubMed]

(C) 2020 by the authors. Licensee MDPI, Basel, Switzerland. This article is an open access article distributed under the terms and conditions of the Creative Commons Attribution (CC BY) license (http://creativecommons.org/licenses/by/4.0/). 